\title{
New iron(II) cyclopentadienyl derivative complexes: Synthesis and antitumor activity against human leukemia cancer cells
}

Andreia Valente $^{\mathrm{a}}$, Ana Margarida Santos ${ }^{\mathrm{a}}$, Leonor Côrte-Real ${ }^{\mathrm{a}}$, M. Paula Robalo ${ }^{\mathrm{b}, \mathrm{c}}$, Virtudes Moreno $^{\mathrm{d}}$, Mercè Font-Bardia ${ }^{\mathrm{e}}$, , Teresa Calvet $^{\mathrm{e}}$, f, Julia Lorenzo ${ }^{\mathrm{g}}, \mathrm{M}$. Helena Garcia ${ }^{a}{ }^{*}$

\section{${ }^{a}$ Centro de Ciências Moleculares e Materiais, Faculdade de Ciências da} Universidade de Lisboa, Campo Grande, 1749-016 Lisboa, Portugal

b Área Departamental de Engenharia Química, Instituto Superior de Engenharia de Lisboa, Rua Conselheiro Emídio Navarro, 1, 1959-007 Lisboa, Portugal

c Centro de Química Estrutural, Complexo I, Instituto Superior Técnico, Universidade de Lisboa, Av. Rovisco Pais, 1049-001 Lisboa, Portugal

$\mathrm{d}$ Department de Química Inorgànica, Universitat de Barcelona, Martí y Franquès 1-11, 08028 Barcelona, Spain

e Cristal.lografia, Mineralogia i Dipòsits Minerals, Universitat de Barcelona, Martí y Franquès s/n, 08028 Barcelona, Spain

${ }^{\mathrm{f}}$ Centre Cientific i Tecnològic (CCiTUB), Universitat de Barcelona, Sole Sabaris 1-3, 08028 Barcelona, Spain

g Institut de Biotecnologia i de Biomedicina, Universitat Autònoma de Barcelona, 08193 Bellaterra, Barcelona, Spain

* Corresponding author.

E-mail address: lena.garcia@fc.ul.pt (M.H. Garcia). 
40 ABSTRACT

41 A new family of " $\mathrm{Fe}^{\mathrm{II}}\left(\eta^{5}-\mathrm{C}_{5} \mathrm{H} 5\right)$ " half sandwich compounds bearing a N-heteroaromatic ligand 42 coordinated to the iron center by a nitrile functional group has been synthesized and fully characterized 43 by NMR and UVeVis spectroscopy. X-ray analysis of single crystal was achieved for complexes 1 and 443 , which crystallized in the monoclinic P2 $1 / \mathrm{c}$ and monoclinic P2 $1 / \mathrm{n}$ space groups, respectively. Studies 45 of interaction of these five new complexes with plasmid pBR322 DNA by atomic force microscopy 46 showed very strong and different types of interaction. Antiproliferative tests were examined on human 47 leukemia cancer cells (HL-60) using the MTT assay, and the IC50 values revealed excellent 48 antiproliferative activity compared to cisplatin. 
50

51

52

\section{Introduction}

Organometallic chemistry emerged in the recent years as an attractive field for the search of new compounds as potential drugs for medicinal chemistry, in particular for chemotherapy. In this frame, metallocene derivatives have appeared at the end of the 1970s with the pioneering work of Köpf and Köpf-Maier involving the antitumor activity of early transition-metal cyclopentadienyl complexes [1]. The promising results obtained for dichloride metallocenes $\left(\mathrm{Cp}_{2} \mathrm{MCl}_{2}\right.$, where $\mathrm{M}=\mathrm{Ti}, \mathrm{V}, \mathrm{Nb}, \mathrm{Mo} ; \mathrm{Cp}=\eta^{5}$-cyclopentadienyl $)$ showing antitumor activity against numerous tumors, such as Ehrlich ascites tumor, B16 melanoma, colon 38 carcinoma and Lewis lung carcinoma, as well as against several human tumors heterotransplanted to athymic mice, certainly constitute an important impulsion for the interest of this area [2]. Titanium dichloride, $\left(\eta^{5}-\mathrm{C}_{5} \mathrm{H}_{5}\right) 2 \mathrm{TiCl}_{2}$, was the first of such species in clinical trials [3]. Nevertheless, problems related with formulation led to the abandonment of titanocene dichloride in Phase II clinical trials [4 -6]. Ferrocene derivatives also appeared with promising results showing activity against Rauscher leukemia virus and EAT in CF1 mice [7,8] and in P388 leukemia cells [9] reinoculated tumors [10]. Particularly, the ferrocifens family, which is a ferrocene derivative of tamoxifen (Astra Zeneca, London, UK e the drug used for treating breast cancer), has revealed good cytotoxicity activities. However, these molecules suffer from poor bioavailability restricting them from entering clinical trials. In order to overcome this limitation and advance toward clinical studies, several formulations are being tested, such as nanoparticles, lipid nanocapsules and cyclodextrins [11]. 
The half-sandwich family of compounds emerged more recently using different central metals and has revealed potentialities as anticancer drugs. The particular geometry of piano stool compounds provides a good scaffold for building new molecules by changing the coordinated arene, which can be $\eta^{6}$ or $\eta^{5}$-bonded, the

9 chelated active ligand and also the coligands. In this context, $\left[\mathrm{Ru}\left(\eta^{6}\right.\right.$-arene $\left.)(\mathrm{X})(\mathrm{Y}-\mathrm{Z})\right]$ complexes (where $\mathrm{Y}-\mathrm{Z}$ is a chelating ligand, and $\mathrm{X}$ is monoanionic ligand) revealed high cytotoxicity against human ovarian tumor cells [12 -15] and they are thought to act through covalent Ru-DNA interactions [16,17]. Related compounds incorporating the 1,3,5-triaza-7-phosphaadamantane (PTA) ligand, such as $\left[\mathrm{Ru}\left(\eta^{6}-\mathrm{p}\right.\right.$-cymene)(PTA)C12] (RAPTA-C), have shown activity against metastases and although their mechanism of action has not been established, a $\mathrm{pH}$ dependent interaction with DNA may be a key component [18]. During the last years, our research group has been exploring a third family of half-sandwich compounds based on the " $\mathrm{Ru}^{\mathrm{II}}\left(\eta^{5}-\mathrm{C}_{5} \mathrm{H}_{5}\right)$ " fragment, with the general formula $\left[\mathrm{Ru}\left(\eta^{5}-\mathrm{Cp}\right)(\mathrm{P}-\mathrm{P})(\mathrm{L})\right][\mathrm{X}]$ (where P-P is a chelating phosphane or two phosphane ligands, $\mathrm{L}$ is a N-heteroaromatic sigma ligand mono or bidentate ligand and $\mathrm{X}$ is a counterion) [19 24]. Our studies showed significant toxicity for a variety of cancer cell lines, namely LoVo and HT29 human colon adenocarcinoma, MiaPaCa pancreatic cancer cell lines, HL-60 human leukemia cancer cells, A2780 human ovarian cancer cells (and the resistant form A2780CisR), MCF7 and MDAMB231 human breast cancer cells (estrogen dependent and independent, respectively) and PC3 human prostate cancer cells, with IC50 values lower than those of cisplatin in most cases [19 -24]. One important advantage of 
112 ruthenium based compounds for therapeutic uses compared to

113 other metal complexes, is pointed out on its ability to mimic iron in

114 binding biologically relevant molecules such as albumin and

115 transferrin and consequently to show much lower toxicity than

116 that of platinum therapies [25]. The success of the coordination of

$117 \mathrm{~N}$-heteroaromatic ligands to the fragment ' $\mathrm{RuCp}$ ' in terms of finding

118 new compounds with important cytotoxicity against several cancer

119 cell lines led us to extend our studies to the analog 'FeCp' derivatives.

120 In this context, we have recently published our first results

121 concerning a new family of compounds with the general

122 cationic structure $\left[\mathrm{Fe}\left(\eta^{5}-\mathrm{Cp}\right)(\mathrm{P}-\mathrm{P})(\mathrm{L})\right]^{+}$, where $\mathrm{L}$ is coordinated to

123 the iron center by the $\mathrm{N}$ atom of the heteroaromatic ligand [26].

124 These new compounds showed values of cytotoxicity against MCF7

125 and HeLa much lower than the ones found for cisplatin in the same

126 experimental conditions.

131 Having in mind to exploit the effect of cytotoxicity of other

ligands coordinated by a different group than a N-heteroaromatic atom, we had previously studied two new $\left[\mathrm{Ru}\left(\eta^{5}\right.\right.$ -

$\left.\mathrm{Cp})\left(\mathrm{PPh}_{3}\right)_{2}(\mathrm{~N} \equiv \mathrm{CL})\right]^{+}$derived compounds where $\mathrm{N} \equiv \mathrm{CL}$ was coordinated

by a nitrile functional group (benzo[1,2-b; 4,3-b']

dithio-phen-2-carbonitrile and [5-(2-thiophen-2-yl)-vinyl]-thiophene-

137 2-carbonitrile]) which were tested against HL-60 cells

138 [20]. The IC50 values obtained after $24 \mathrm{~h}$ of incubation were

$139 \quad 1.46 \pm 0.25$ and $5.89 \pm 0.67 \mathrm{mM}$, respectively, while cisplatin in

140 the same experimental conditions presented a higher IC50 value

141 of $15.61 \pm 1.15 \mathrm{mM}$. These motivating results obtained with

142 ruthenium coordinated nitrile ligands together with our interest 
to continue the exploitation of the cytotoxic properties of ' $\mathrm{FeCp}$ '

compounds led us to the synthesis of a new family of iron nitrile compounds of general formula $\left[\mathrm{Fe}\left(\eta^{5}-\mathrm{Cp}\right)(\mathrm{NCL})(\mathrm{P}-\mathrm{P})\right]^{+}$. In the present paper we report the synthesis of compounds of the general formula $\left[\mathrm{Fe}\left(\eta^{5}-\mathrm{Cp}\right)(\mathrm{NCL})(\mathrm{P}-\mathrm{P})\right]^{+}$, where the NCL ligands, 2-quinolinecarbonitrile (L1), 3-quinolinecarbonitrile (L2), 2pyrazinecarbonitrile (L3) or 2,3-pyrazinedicarbonitrile (L4), present on their structures one or two N-heteroaromatic rings. These new compounds were fully characterized and their interaction with plasmid pBR322 DNA was studied by atomic force microscopy.

Moreover, their potentialities as cytotoxic agents against human leukemia cancer cells (HL-60 cells) were evaluated.

Remarkably, our studied compounds revealed IC50 values lower than those of cisplatin. Apoptotic behavior was also evaluated and compared with cisplatin.

\section{Experimental}

\subsection{General procedures}

All syntheses were carried out under dinitrogen atmosphere using current Schlenk techniques and the solvents used were dried using standard methods [27]. [ $\left.\mathrm{Fe}\left(\eta^{5}-\mathrm{C}_{5} \mathrm{H}_{5}\right)(\mathrm{dppe}) \mathrm{I}\right]$ was prepared following the method described in literature [28]. FT-IR spectra were recorded in a Mattson Satellite FTIR spectrophotometer with $\mathrm{KBr}$ pellets; only significant bands are cited in text. ${ }^{1} \mathrm{H},{ }^{13} \mathrm{C}$ and ${ }^{31} \mathrm{P} \mathrm{NMR}$ spectra were recorded on a Bruker Avance 400 spectrometer at probe temperature. The ${ }^{1} \mathrm{H}$ and ${ }^{13} \mathrm{C}$ chemical shifts are reported in parts per million (ppm) downfield from internal $\mathrm{Me}_{4} \mathrm{Si}$ and the ${ }^{31} \mathrm{P} \mathrm{NMR}$ spectra are reported in ppm downfield from external standard, $85 \% \mathrm{H}_{3} \mathrm{PO}_{4}$. Elemental analyses were obtained at Centro de Apoio Científico Tecnológico Á Investigación (C.A.C.T.I.), at Universidade de Vigo, using a Fisons Instruments EA1108 system. Electronic spectra were recorded at room temperature on a Jasco V-560 spectrometer in the range of $200-900 \mathrm{~nm}$.

\subsection{Complexes synthesis}

2.2.1. General procedure applied to the synthesis of the complexes 1-5

To a stirred suspension of $0.5 \mathrm{mmol}$ of [ $\mathrm{FeCp}(\mathrm{dppe}) \mathrm{I}]$ in dichloromethane $(25 \mathrm{~mL})$ was added $0.6 \mathrm{mmol}$ of the adequate ligand ( $\mathrm{L} 1=2$-quinolinecarbonitrile; L2 $=3$-quinolinecarbonitrile; L3 $1 / 42$ pyrazinecarbonitrile; $\mathrm{L} 4=2,3$-pyrazinedicarbonitrile) followed by addition of $0.6 \mathrm{mmol}$ of $\mathrm{TlPF}_{6}$ (for 
complexes 1, 2, 3 and 4) or $\mathrm{AgCF}_{3} \mathrm{SO}_{3}$ (for complex 3). After refluxing for a period of 5-6 h the color changed from gray to orange reddish. The reaction mixture was cooled down to room temperature and the solution was filtered to eliminate the $\mathrm{TlCl}$ or the $\mathrm{AgCl}$ precipitate. The solvent was then removed under vacuum and the residue was washed with $\mathrm{n}$-hexane $(2 \times 10 \mathrm{~mL})$. Dark red crystals were obtained after recrystalization from dichloromethane/n-hexane solutions.

Compound 5 was obtained by stirring for $90 \mathrm{~min}$, a suspension of $0.32 \mathrm{~g}(0.5 \mathrm{mmol})$ of [FeCp(dppe)I] and $\mathrm{TlPF}_{6}(0.21 \mathrm{~g}, 0.6 \mathrm{mmol})$, in dichloromethane $(25 \mathrm{~mL})$ to which a solution of 2,3-dicianopyrazine in dichloromethane $(0.078 \mathrm{~g} ; 0.6 \mathrm{mmol})$ was slowly added. The obtained purple solution was dried and washed with n-hexane, giving a powder, which after recrystalization from dichloromethane/n-hexane, gave needle shaped purple crystals.

\subsection{2. $[\mathrm{FeCp}(\mathrm{dppe})(2-c q)]\left[\mathrm{PF}_{6}\right], 1$}

Dark $^{-}$red; Yield $=81 \%$. IR $\left(\mathrm{KBr}, \mathrm{cm}^{-1}\right): v\left(\mathrm{C} \equiv \mathrm{N}\right.$, stretch) 2208, $v\left(\mathrm{PF}_{6}\right) 837$ and 557. ${ }^{1} \mathrm{H}$ NMR ((CD $\left.)_{2} \mathrm{CO}, \mathrm{Me}_{4} \mathrm{Si}, \delta / \mathrm{ppm}\right): 8.30$ (d, 1, $\left.\mathrm{H}_{10}\right) ; 8.15$ (t, 4, dppe); 7.96 (dd, 2, $\mathrm{H}_{4}$ p H7); 7.88 (t, 1, $\mathrm{H}_{6}$ ); 7.73 (t, 1, H5); 7.53 (m,16, dppe); 6.78 (d,1, H9) 4.75 (s, 5, $\left.\mathrm{h}^{5}-\mathrm{C}_{5} \mathrm{H}_{5}\right) ; 2.80$ (m, 4, $\mathrm{CH}_{2}$-dppe). ${ }^{13} \mathrm{C}$ NMR ((CD3)2CO, Me4Si, $\delta / p p m): 148.3(\mathrm{C} 8) ; 138.0(\mathrm{C} 9) ; 137.6-137.0\left(\mathrm{C}_{\mathrm{q}}\right.$, dppe); 133.8 (CH-, dppe); 133.1 $(\mathrm{C} \equiv \mathrm{N}) ; 132.5$ (CH-, dppe); $132.2\left(\mathrm{C}_{6}\right) ; 131.6-131.4$ (CH-, dppe); $130.3\left(\mathrm{C}_{5}\right) ; 130.0\left(\mathrm{C}_{4}\right)$; $129.9(\mathrm{CH}-$, dppe $\left.+\mathrm{C}_{3}\right) ; 129.4\left(\mathrm{C}_{2}\right) ; 128.9\left(\mathrm{C}_{7}\right) ; 123.8\left(\mathrm{C}_{10}\right) ; 81.4(\mathrm{Cp}) ; 28.4\left(-\mathrm{CH}_{2}-\right.$, dppe $) .{ }^{31} \mathrm{P}\left(\left(\mathrm{CD}_{3}\right)_{2} \mathrm{CO}, \mathrm{d} / \mathrm{ppm}\right)$ : 96.2 (s, dppe); -144.2 (setp, $\mathrm{PF}_{6}$ ). UV-Vis. in $\mathrm{CH}_{2} \mathrm{Cl}_{2}, \lambda \max / \mathrm{nm}\left(\varepsilon / \mathrm{M}^{-1} \mathrm{~cm}^{-1}\right): 240(73,195), 385$ (6049), 441 (6893). UV-Vis. In DMSO, $\lambda \max / \mathrm{nm}\left(\varepsilon / \mathrm{M}^{-1} \mathrm{~cm}^{-1}\right)$ : 392 (Sh), 455 (7669). Elemental analysis (\%) Found: C, 59.50; H, 4.30; N, 3.40; Calc. for $\mathrm{C}_{41} \mathrm{H}_{35} \mathrm{~N}_{2} \mathrm{P}_{3} \mathrm{~F}_{6} \mathrm{Fe} \cdot 0.1 \mathrm{CH}_{2} \mathrm{Cl}_{2}$ (826.9): C, 59.70.16; $\mathrm{H}$, $4.30 ; \mathrm{N}, 3.40$.

\subsection{3. $[\mathrm{FeCp}(\mathrm{dppe})(3-\mathrm{cq})]\left[\mathrm{PF}_{6}\right], 2$}

Dark ${ }^{-}$red; Yield: $80 \%$. IR $\left(\mathrm{KBr}, \mathrm{cm}^{-1}\right): v\left(\mathrm{C} \equiv \mathrm{N}\right.$, stretch) 2210, $v\left(\mathrm{PF}_{6}\right) 837$ and $557 .{ }^{1} \mathrm{H} \mathrm{RMN}$ $\left(\left(\mathrm{CD}_{3}\right)_{2} \mathrm{CO}, \mathrm{Me}_{4} \mathrm{Si}, \delta / \mathrm{ppm}\right): 8.15$ (t, 4, $\mathrm{C}_{6} \mathrm{H}_{5}$-dppe); 8.00 (d, 1, $\left.\mathrm{H}_{5}\right) ; 7.92$ (m, 2, $\left.\mathrm{H}_{3}+\mathrm{H}_{7}\right) ; 7.85$ (d, 1,

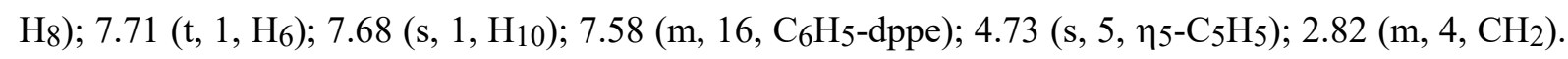
13C NMR ((CD3) $\left.2 \mathrm{CO}, \mathrm{Me}_{4} \mathrm{Si}, \delta / \mathrm{ppm}\right): 149.9\left(\mathrm{C}_{3}\right) ; 148.8\left(\mathrm{C}_{2}\right) ; 142.3\left(\mathrm{C}_{10}\right) ; 137.7$ - 137.1 (Cq, dppe); 134.0 (CH-, dppe); 133.8 (C7); 132.4 (CH-, dppe); 131.7 - 131.4 (CH-, dppe); 130.1 (C5); 130.0 (CH-, dppe); $129.4\left(\mathrm{C}_{8}\right) ; 129.3\left(\mathrm{C}_{6}\right) ; 126.5\left(\mathrm{C}_{4}\right) ; 107.1(\mathrm{C} 9) ; 81.1$ (Cp); 28.5 (-CH2-, dppe); $\mathrm{C}_{1}$ is overlapped by dppe signals. ${ }^{31} \mathrm{P}$ RMN ((CD) $\left.)_{2} \mathrm{CO}, \delta / \mathrm{ppm}\right): 97.1$ (s, dppe); -144.2 (setp, $\left.\mathrm{PF}_{6}\right) . \mathrm{UV}-\mathrm{V}$ is in $\mathrm{CH}_{2} \mathrm{Cl}_{2}$, $\lambda \max / \mathrm{nm}\left(\varepsilon / \mathrm{M}^{-1} \mathrm{~cm}^{-1}\right): 239$ (75,639), 376 (7169), 429 (5136). UV - Vis in DMSO, $\lambda_{\max } / \mathrm{nm}\left(\varepsilon / \mathrm{M}^{-1} \mathrm{~cm}^{-}\right.$ $\left.{ }^{1}\right)$ : 386 (6559), 442 (7292). Elemental analysis (\%) Found: C, 59.10; H, 4.30; N, 3.40; $\mathrm{C}_{41} \mathrm{H}_{35} \mathrm{~N}_{2} \mathrm{P}_{3} \mathrm{~F} 6 \mathrm{Fe}$ (826.9): C, 59.2; H, 4.30; N, 3.30. 
Dark red; Yield: $80 \%$. IR $\left(\mathrm{KBr}, \mathrm{cm}^{-1}\right): \mathrm{n}\left(\mathrm{C} \equiv \mathrm{N}\right.$, stretch) $2212,{ }\left(\mathrm{CF}_{3} \mathrm{SO}_{3}\right) 1269 .{ }^{1} \mathrm{H} \mathrm{NMR}\left(\left(\mathrm{CD}_{3}\right)_{2} \mathrm{CO}\right.$, Me4Si, $\delta / \mathrm{ppm}$ ): 8.15 (t, 4, $\mathrm{C}_{6} \mathrm{H}_{5}$-dppe); 8.01 (d, 1, H5); 7.92 (m, 2, $\mathrm{H}_{3}+\mathrm{H} 7$ ); 7.87 (d, 1, H8); 7.71 (m, 2, $\left.\mathrm{H}_{10}+\mathrm{H}_{6}\right) ; 7.63$ (t, 4, $\mathrm{C}_{6} \mathrm{H}_{5}$-dppe); 7.57 (m, 12, $\mathrm{C}_{6} \mathrm{H}_{5}$-dppe); 4.74 (s, 5, $\left.\eta^{5}-\mathrm{C}_{5} \mathrm{H}_{5}\right) ; 2.80$ (m, 4, $\mathrm{CH}_{2}$ ). ${ }^{13} \mathrm{C}$ NMR ((CD 3$\left.)_{2} \mathrm{CO}, \mathrm{Me}_{4} \mathrm{Si}, \delta / \mathrm{ppm}\right): 149.7\left(\mathrm{C}_{3}\right) ; 148.6\left(\mathrm{C}_{2}\right) ; 142.6\left(\mathrm{C}_{10}\right) ; 137.7$-137.4 (Cq, dppe); 134.0 (CH-, dppe); 133.8 (C7); 132.4 (CH-, dppe); 132.1 (C1); 131.7 - 131.4 (CH-, dppe); 130.2 (C5); 130.0 (CH-, dppe); $129.4\left(\mathrm{C}_{8}\right) ; 129.3\left(\mathrm{C}_{6}\right) ; 126.6\left(\mathrm{C}_{4}\right) ; 107.1\left(\mathrm{C}_{9}\right) ; 81.1(\mathrm{Cp}) ; 28.5\left(-\mathrm{CH}_{2}\right.$, dppe). ${ }^{31} \mathrm{P}$ $\mathrm{RMN}\left(\mathrm{CD}_{3} \mathrm{Cl}_{3}, \delta / \mathrm{ppm}\right): 97.1$ (s, dppe). UV - Vis in $\mathrm{CH}_{2} \mathrm{Cl}_{2}, \lambda_{\max } / \mathrm{nm}\left(\varepsilon / \mathrm{M}^{-1} \mathrm{~cm}^{-1}\right): 239(51,562), 369$ (3559), 428 (2371). UV - Vis in DMSO, $\lambda_{\max } / \mathrm{nm}\left(\varepsilon / \mathrm{M}^{-1} \mathrm{~cm}^{-1}\right): 386$ (4380), 442 (4798). Elemental analysis (\%) Found: $\mathrm{C}, 57.4 ; \mathrm{H} 4.2 ; \mathrm{N}, 3.08 ; \mathrm{C}_{42} \mathrm{H}_{37} \mathrm{~N}_{2} \mathrm{P}_{2} \mathrm{~F}_{3} \mathrm{SO}_{3}-\mathrm{Fe} \cdot \mathrm{CH}_{2} \mathrm{Cl}_{2}$ : C, 56.8; $\mathrm{H}, 4.32 ; \mathrm{N}, 3.08$.

\subsection{5. [FeCp(dppe)(cpz)][PF6], 4}

Red; Yield: $85 \%$. IR $\left(\mathrm{KBr}, \mathrm{cm}^{-1}\right)$ : $\mathrm{n}\left(\mathrm{C} \equiv \mathrm{N}\right.$, stretch) 2218, $\left(\mathrm{PF}_{6}\right) 837$ and 557. ${ }^{1} \mathrm{H}$ NMR $\left(\left(\mathrm{CD}_{3}\right)_{2} \mathrm{CO}\right.$, Me4Si, $\delta / \mathrm{ppm}) 8.67$ (d, 1, H4); 8.55 (d, 1, H5), 8.05 (m, 4, $\left.\mathrm{C}_{6} \mathrm{H}_{5}\right), 7.88$ (s, 1, H3), 7.56 - 7.48 (m, 16, $\left.\mathrm{C}_{6} \mathrm{H}_{5}\right), 4.75$ (s, 5, $\left.\eta^{5}-\mathrm{C}_{5} \mathrm{H}_{5}\right) ; 2.79\left(\mathrm{~m}, 4, \mathrm{CH}_{2}\right) .{ }^{13} \mathrm{C} \mathrm{NMR}\left(\left(\mathrm{CD}_{3}\right)_{2} \mathrm{CO}, \mathrm{Me}_{4} \mathrm{Si}, \delta / \mathrm{ppm}\right): 148.9(\mathrm{C} 3), 147.8$ (C4), 146.2 (C5), 137.4 - 137.0 (Cq, dppe); 133.8 (CH-, dppe); 132.5 (CH-, dppe); 131.5 (CH-, dppe); 130.0 (CH-, dppe); 81.7 (Cp); 28.4 (-CH2-, dppe). ${ }^{31} \mathrm{P}$ NMR ((CD3) $\left.2 \mathrm{CO}, \delta / \mathrm{ppm}\right): 96.10$ (s, dppe); -144.2 (setp, $\mathrm{PF}_{6}$ ). UV-Vis in $\mathrm{CH}_{2} \mathrm{Cl}_{2}, \lambda_{\max } / \mathrm{nm}\left(\varepsilon / \mathrm{M}^{-1} \mathrm{~cm}^{-1}\right)$ : 264 (20,282), 388 (2564), 445 (2895). UV-Vis in DMSO, $\lambda_{\max } / \mathrm{nm}\left(\varepsilon / \mathrm{M}^{-1} \mathrm{~cm}^{-1}\right)$ : 446 (5225). Elemental analysis (\%) Found: C, 55.75; H, 4.1; N, 5.35; Calc. for $\mathrm{C}_{36} \mathrm{H}_{32} \mathrm{~N}_{3} \mathrm{P}_{3} \mathrm{~F}_{6} \mathrm{Fe} \cdot 1 / 10 \mathrm{CH}_{2} \mathrm{Cl}_{2}$ : C, 55.74; H, 4.17; N, 5.40 .

\subsection{6. $[\mathrm{Fe} C \mathrm{P}(\mathrm{dppe})(2,3-d c p z)]\left[\mathrm{PF}_{6}\right], 5$}

Purple; yield: $86 \%$. IR $\left(\mathrm{KBr}, \mathrm{cm}^{-1}\right): \mathrm{n}\left(\mathrm{C} \equiv \mathrm{N}\right.$, stretch) 2198, $\mathrm{n}\left(\mathrm{PF}_{6}\right) 837$ and 559. ${ }^{1} \mathrm{H} \mathrm{RMN}\left(\mathrm{CDCl}_{3}\right.$, $\mathrm{Me} 4 \mathrm{Si}, \delta / \mathrm{ppm}): 8.84-8.81\left(\mathrm{~m}, 2, \mathrm{H}_{4}+\mathrm{H}_{5}\right) ; 8.00$ (t, 4, $\left.\mathrm{C}_{6} \mathrm{H}_{5}\right) ; 7.48$ (m, 16, $\left.\mathrm{C}_{6} \mathrm{H}_{5}\right) ; 4.86\left(\mathrm{~s}, 5, \eta^{5}-\mathrm{C}_{5} \mathrm{H}_{5}\right)$; 2.85 (m, 4, $\left.\mathrm{CH}_{2}\right) .{ }^{13} \mathrm{C} \mathrm{NMR}\left(\left(\mathrm{CD}_{3}\right)_{2} \mathrm{CO}, \mathrm{Me}_{4} \mathrm{Si}, \delta / \mathrm{ppm}\right): 148.8\left(\mathrm{C}_{4}\right) ; 147.0\left(\mathrm{C}_{5}\right) ; 137.1-136.6(\mathrm{Cq}$, dppe); 133.8 (CH-, dppe); $133.2\left(\mathrm{C}_{2}+\mathrm{C}_{3}\right) ; 131.7$ (CH-, dppe); 130.1 (CH-, dppe); 120.0 (CH-, dppe); $128.7\left(\mathrm{C}_{1}\right) ; 114.6\left(\mathrm{C}_{6}\right) ; 82.7$ (Cp); 28.6 (-CH2-, dppe). ${ }^{31} \mathrm{P} \mathrm{RMN}\left(\left(\mathrm{CD}_{3}\right)_{2} \mathrm{CO}, \delta / \mathrm{ppm}\right): 95.4$ (s, dppe); 144.27 (setp, $\mathrm{PF} 6$ ). UV- Vis in $\mathrm{CH}_{2} \mathrm{Cl}_{2}, \lambda_{\max } / \mathrm{nm}\left(\varepsilon / \mathrm{M}^{-1} \mathrm{~cm}^{-1}\right): 266(12,201), 521$ (2521). UV-Vis in DMSO, $\lambda \max / \mathrm{nm}\left(\varepsilon / \mathrm{M}^{-1} \mathrm{~cm}^{-1}\right)$ : 512 (5710). Elemental analysis (\%) Found: C, 55.10; H, 4.0; N, 6.90; Calc. for $\mathrm{C}_{41} \mathrm{H}_{35} \mathrm{~N}_{2} \mathrm{P}_{3} \mathrm{~F}_{6} \mathrm{Fe} \cdot 0.2 \mathrm{CH}_{2} \mathrm{Cl}_{2}$ (811.40): C, 55.94; H, 3.93; N, 7.05.

\subsection{Crystal structure determination of [FeCp(dppe)(2-cq)][PF6] 1 and $[\mathrm{Fe} C p($ dppe $)(3-c q)]\left[\mathrm{CF}_{3} \mathrm{SO}_{3}\right]$} 3

Prismatic crystals $(0.1 \times 0.1 \times 0.2 \mathrm{~mm}$ and $0.2 \times 0.1 \times 0.1 \mathrm{~mm}$ respectively) were selected and mounted on a MAR345 diffractometer with an image plate detector. Intensities were collected with graphite monochromatized Mo K $\alpha$ radiation. Lorentzpolarization and absorption corrections were made. The structures were solved by Direct methods, using SHELXS computer program [29] and refined by full- 
matrix least-squares method with SHELX93 computer program [30], (very negative intensities were not assumed). The function minimized was $\left.\Sigma \mathrm{w}|| \mathrm{Fo}\right|^{2}-\left.|\mathrm{Fc}|^{2}\right|^{2}$, where $\omega=\left[\sigma^{2}(\mathrm{I})+(0.0566 \mathrm{P})^{2}+0.4472 \mathrm{P}\right]^{-1}$, and $\mathrm{P}=\left(|\mathrm{Fo}|^{2}+2|\mathrm{Fc}|^{2}\right) / 3, f, f$ ' and $f$ " were taken from International Tables of X-Ray Crystallography [31]. All $\mathrm{H}$ atoms were located from a difference synthesis and refined with an overall isotropic temperature factor. CCDC 939633 and 939634 contain the supplementary crystallographic data for this paper. These data can be obtained free of charge from the Cambridge Crystallographic Data Centre via www. ccdc.cam.ac.uk/data_request/cif.

\subsection{Electrochemical experiments}

The electrochemical experiments were performed on an EG\&G Princeton Applied Research Model 273A potentiostat/galvanostat and monitored with a personal computer loaded with Electrochemistry PowerSuite v2.51 software from Princeton Applied Research. Cyclic voltammograms were obtained in $0.1 \mathrm{M}$ or $0.2 \mathrm{M}$ solutions of $\left[\mathrm{NBu}_{4}\right]\left[\mathrm{PF}_{6}\right]$ in $\mathrm{CH}_{3} \mathrm{CN}$ or $\mathrm{CH}_{2} \mathrm{Cl}_{2}$ respectively, using a three-electrode configuration cell with a platinum-disk working electrode $(1.0 \mathrm{~mm}$ diameter) probed by a Luggin capillary connected to a silver-wire pseudo-reference electrode and a Pt wire counter electrode. The electrochemical experiments were performed under a dinitrogen atmosphere at room temperature. The redox potentials were measured in the presence of ferrocene as the internal standard and the redox potential values are normally quoted relative to the SCE by using the ferrocenium/ferrocene redox couple $\left(\mathrm{E}_{1 / 2}=0.46\right.$ or $0.40 \mathrm{~V}$ vs. $\mathrm{SCE}$ for $\mathrm{CH}_{2} \mathrm{Cl}_{2}$ or $\mathrm{CH}_{3} \mathrm{CN}$, respectively) [32]. The supporting electrolyte was purchased from Fluka, electrochemical grade was dried under vacuum for several hours and used without further purification. Reagent grade acetonitrile and dichloromethane were dried over $\mathrm{P}_{2} \mathrm{O}_{5}$ and $\mathrm{CaH}_{2}$, respectively, and distilled under dinitrogen atmosphere before use.

\subsection{DNA interaction studies}

\subsubsection{Formation of drugeDNA complexes}

Deionized Milli-Q water (18.2 M 2 ) was filtered through 0.2-nm FP030/3 filters (Schleicher \& Schuell) and centrifuged at $4.000 \mathrm{~g}$ prior to use. pBR322 DNA was heated at $60^{\circ} \mathrm{C}$ for $10 \mathrm{~min}$ to obtain open circular (OC) form. To stock aqueous solutions of plasmid pBR322 DNA in Hepes buffer (4 mM Hepes, $\mathrm{pH} 7.4 / 2 \mathrm{mM} \mathrm{MgCl}_{2}$ ) were added aqueous solutions (with $4 \%$ of DMSO) of complexes 1-5 in a relationship DNA base pair to complex 10:1. In parallel experiments, blank sample of free DNA and DNA complex solutions were equilibrated at $37^{\circ} \mathrm{C}$ for $4 \mathrm{~h}$ in the dark shortly thereafter.

\subsubsection{AFM imaging}

Atomic force microscopy (AFM) samples were prepared by casting a 3- $\mu \mathrm{L}$ drop of test solution onto freshly cleaved green mica disks as support. The drop was allowed to stand undisturbed for 3 min to favor the adsorbate-substrate interaction. Each DNA-laden disk was rinsed with Milli-Q water and was blown dry with clean compressed argon gas directed normal to the disk surface. Samples were stored over silica prior to AFM imaging. All AFM observations were made with a Nanoscope III Multimode AFM (Digital Instrumentals, Santa Barbara, CA). Nano-crystalline Si cantilevers of 125-nm length with a spring constant of $50 \mathrm{~N} / \mathrm{m}$ average ended with conical-shaped Si probe tips of 10-nm apical radius and cone angle of $35^{\circ}$ were used. High-resolution topographic AFM images were performed in air at room temperature (relative humidity $<40 \%$ ) on different specimen areas of $2 \times 2 \mathrm{~mm}$ operating in intermittent contact mode at a rate of 1-3 Hz. 


\subsection{Growth inhibition assays}

Antiproliferative activity of these new iron complexes, and cisplatin, was tested in a cell culture system using the human acute promyelocytic leukemia cell line HL-60 (American Type Culture Collection (ATCC)). The cells were grown in RPMI-1640 medium supplemented with $10 \%(\mathrm{v} / \mathrm{v})$ heat inactivated fetal bovine serum, $2 \mathrm{mmol} / \mathrm{L}$ glutamine (Invitrogen, Inc.) in a highly humidified atmosphere of $95 \%$ air with $5 \% \mathrm{CO}_{2}$ at $37{ }^{\circ} \mathrm{C}$. Growth inhibitory effect was measured by the microculture tetrazolium [3(4,5- dimethylthiazol-2-yl)-2,5-diphenyltetrazolium bromide, MTT assay [33]. Cells were seeded at density 104 cells/well in $100 \mathrm{~mL}$ of culture medium and after that cells were treated with different concentrations ranging from 0 (culture medium) to $200 \mu \mathrm{M}$ of compounds in $100 \mu \mathrm{l}$ of culture medium. The exact concentrations assayed were $0.1,0.24,0.5,0.75,1,2.5,5,10,25,50,100$ and $200 \mu \mathrm{M}$. All the assays were done in quadruplicate and three independent assays were realized. After incubation at $37^{\circ} \mathrm{C}$ during $24 \mathrm{~h}$ or $72 \mathrm{~h}$, without washing, $20 \mu \mathrm{l}$ of soluble tetrazolium salt was added to each well and incubated 3 additional hours. As we used soluble tretrazolium salts we determined the amount of formazan directly reading the absorbance at $490 \mathrm{~nm}$ in a spectrophotometric plate reader (Labsystems iEMS Reader MF). Cytotoxicity was evaluated in terms of cell growth inhibition in treated cultures versus that in untreated controls. IC50, the concentration of compound at which cell proliferationwas $50 \%$ of that observed in control cultures, were obtained by GraphPad Prism software, version 4.0. Experiments were repeated at least three times to get the mean values.

\subsection{Apoptosis assays}

Induction of apoptosis in vitro by iron compounds was determined by a flow cytometric assay with Annexin V-FITC by usingan Annexin V-FITC Apoptosis Detection Kit (Roche) [34]. Exponentially growing HL-60 cells in 6-well plates $\left(5 \times 10^{5}\right.$ cells/well) were exposed to concentrations equal to the IC50 of the platinum and iron drugs for $24 \mathrm{~h}$. After, the cells were subjected to staining with the Annexin V-FITC and propidiumiodide. The amount of apoptotic cells was analyzed by flow cytometry (BD FACSCalibur). 


\section{Results and discussion}

\subsection{Synthesis of $\mathrm{Fe}(\mathrm{II})$ complexes}

Five new cationic iron(II) complexes ( $\left(\mathrm{e}_{5}\right)$ of the general type $\left[\mathrm{Fe}\left(\eta^{5}-\mathrm{C}_{5} \mathrm{H}_{5}\right)(\mathrm{dppe}) \mathrm{L}\right][\mathrm{X}]$ where $\mathrm{L}=2$ quinolinecarbonitrile (L1), 3-quinolinecarbonitrile (L2), 2-pyrazinecarbonitrile (L3) or 2,3pyrazinedicarbonitrile (L4) and $\mathrm{X}=\mathrm{PF}_{6}$ or $\mathrm{CF}_{3} \mathrm{SO}_{3}$ were prepared by $\sigma$ coordination of the functional nitrile $\mathrm{N} \equiv \mathrm{C}$ group of the L1-L4 ligands (Scheme 1). Compounds were obtained in good yields (80-86\%), by halide abstraction from $\left[\mathrm{Fe}\left(\eta^{5}-\mathrm{C}_{5} \mathrm{H}_{5}\right)(\right.$ dppe $\left.) \mathrm{I}\right]$ with thallium hexafluorophosphate or silver triflate, in dichloromethane, in the presence of a slight excess of the adequate ligand and recrystallized from dichloromethane/n-hexane solutions. The new compounds are stable in cellular media for several hours (Fig. S1, in SI) and were all fully characterized by FT-IR, ${ }^{1} \mathrm{H},{ }^{13} \mathrm{C}$ and ${ }^{31} \mathrm{P}$ NMR spectroscopies; the elemental analyses were in accordance with the proposed formulations. The structures of compounds 1 and 3 were also characterized by X-ray diffraction studies (see below).

Solid state FT-IR spectra ( $\mathrm{KBr}$ pellets) of the complexes present the characteristic bands of the cyclopentadienyl ligand $\left(\approx 3050 \mathrm{~cm}^{-1}\right)$, the $\mathrm{PF}_{6}\left(840\right.$ and $\left.550 \mathrm{~cm}^{-1}\right)$ or $\mathrm{CF}_{3} \mathrm{SO}_{3}\left(1250 \mathrm{~cm}^{-1}\right)$ anion and the characteristic stretching vibration of the nitrile functional group in the range $2200 \mathrm{e} 2220 \mathrm{~cm}^{-1}$. The coordination of the ligand to the metal center lead to a weakness of the $v_{\mathrm{N} \equiv \mathrm{C}}$ of $\sim-20 \mathrm{~cm}^{-1}$ for compounds $1-4$ being this value somehow higher $\left(-47 \mathrm{~cm}^{-1}\right)$ for compound 5, probably due to the presence of the second nitrile acceptor group. These negative shifts observed on $v_{\mathrm{N}} \equiv \mathrm{C}$ are in good agreement with the values found before for other related $\eta^{5}$-monocyclopentadieny iron compounds [35-37] and show an enhanced $\pi$-backdonation from the metal $d$ orbitals to the $\pi^{*}$ orbital of the $\mathrm{N} \equiv \mathrm{C}$ group leading to a decreased $\mathrm{N} \equiv \mathrm{C}$ bond order.

${ }^{1} \mathrm{H}$ NMR chēmical shifts of the cyctopentadienyl ring are displayed in the characteristic range of monocationic iron(II) complexes (4.70-4.90 ppm, Table 1). The effect of coordination on the nitrile ligands is observed through the shielding of the ortho protons relatively to $\mathrm{N} \equiv \mathrm{C}$ coordination position $(\approx 1.20 \mathrm{ppm})$ in compounds $2-4$ indicating an electronic flow towards the heteroaromatic ligand due to $\pi$-backdonation involving the metal center. Furthermore, an increased electronic density was also found in compound 1 in both ortho $(\approx 0.30 \mathrm{ppm})$ and meta $(\approx 1.20 \mathrm{ppm})$ protons with special relevance for the meta position (opposite to $\mathrm{N}$ in the heteroaroamtic ring) probably due to a higher contribution of the corresponding resonance form. The electronic flow in compound 1 is still observed in the second fused ring $(\approx 0.20 \mathrm{ppm})$. This shielding effect on the second fused ring was also observed for compounds 2 and 3. Here, the difference in the anion did not cause any additional effect. Relatively to the pyrazinecarbonitrile complexes ( 4 and 5) both protons suffered a shielding of about $0.30 \mathrm{ppm} .{ }^{13} \mathrm{C}$ NMR data confirm the evidence found for proton spectra. The $\mathrm{Cp}$ ring chemical shifts are in the range usually observed for $\mathrm{Fe}$ (II) cationic derivatives, a significant deshielding (up to $\approx 14 \mathrm{ppm}$ ) being observed on the carbon of the $\mathrm{N} \equiv \mathrm{C}$ functional group upon coordination. All the other carbons of the chromophore ligand were only slightly deshielded or remained almost unchanged for the studied compounds. ${ }^{31} \mathrm{P}$ NMR data of the complexes showed the typical septuplet of the $\mathrm{PF}_{6}$ anion at approximately - $144 \mathrm{ppm}$ (with the exception of compound 3 where the $\mathrm{PF}_{6}$ anion was replaced by $\mathrm{CF}_{3} \mathrm{SO}_{3}$ ). Moreover, a single sharp signal corresponding to the phosphine coligand ( $\approx 96 \mathrm{ppm})$ was observed for all the complexes, revealing the equivalency of the two phosphorus atoms, together with the expected deshielding upon coordination, in accordance with its $\sigma$ donor character. Table 1 displays the ${ }^{1} \mathrm{H}$ NMR chemical shifts of the ligands (L1-L4) and corresponding complexes (1-5) in $\left(\mathrm{CD}_{3}\right)_{2} \mathrm{CO}$. 


\subsection{UV-Vis studies}

The optical absorption spectra of these five new Fe(II) complexes and all the ligands were recorded in $10^{-3}-10^{-5} \mathrm{M}$ dichloromethane solutions in order to identify any MLCT absorption and $\pi-\pi^{*}$ absorption bands expected for these complexes (Table 2). The electronic spectra of all the compounds showed intense absorption bands in the UV region, which can be assigned to electronic transitions occurring both in the organometallic fragment $\{\mathrm{FeCp}(\mathrm{dppe})\}^{+}(\lambda \approx 235-260 \mathrm{~nm})$ and in the coordinated chromophore $(\lambda \approx 260-450 \mathrm{~nm}$ ) (Fig. 1). Additional charge transfer (CT) bands were also observed in all studied complexes. In fact, all complexes presented one band compatible with a MLCT nature, which was confirmed by solvatochromism studies in DMSO (example given in Fig. 2 for complex 1).

3.3. X-ray structural studies of the complexes $\left[\mathrm{Fe}\left(\eta^{5}-\mathrm{C}_{5} \mathrm{H}_{5}\right)(\mathrm{dppe})(2-\mathrm{cq})\right][\mathrm{PF} 6] 1$ and $\left[\mathrm{Fe}\left(\eta^{5}\right.\right.$ $\left.\mathrm{C}_{5} \mathrm{H}_{5}\right)\left(\right.$ dppe)(3-cq)][CF $\left.3 \mathrm{SO}_{3}\right] 3$

Suitable crystals for X-ray diffraction studies of the complexes $\left[\mathrm{Fe}\left(\eta^{5}-\mathrm{C}_{5} \mathrm{H}_{5}\right)(\mathrm{dppe})(2-\mathrm{cq})\right]\left[\mathrm{PF}_{6}\right] 1$ and $\left[\mathrm{Fe}\left(\eta^{5}-\mathrm{C}_{5} \mathrm{H}_{5}\right)(\mathrm{dppe})(3-\mathrm{cq})\right]\left[\mathrm{CF}_{3} \mathrm{SO}_{3}\right] 3$, crystallized in different crystalline systems and space groups (monoclinic $\mathrm{P} 21 / \mathrm{c}$ and monoclinic $\mathrm{P} 21 / \mathrm{n}$ space groups, respectively). Crystal data and structure refinement for both complexes are collected in Table 3. In Fig. 3 and Fig. 4 the molecular structure of both complexes 1 and 3 are respectively presented. Both complexes present the usual distorted threelegged piano stool geometry for $\eta^{5}$-monocyclopentadienyl complexes confirmed by P-Fe-P angles of $86.93 \mathrm{e} 87.11^{\circ}$ and N-Fe-P angles varying from 90.02 to $92.64^{\circ}$, with the remaining $\eta^{5}$-Cp(centroid)-Fe$\mathrm{X}$ (with $\mathrm{X}=\mathrm{N}$ or $\mathrm{P}$ ) angles between 120.40 and $128.39^{\circ}$ (see Table 4 ). These values are within the range found for $\eta^{5}$-monocyclopentadienylmetal nitrile derivatives with coordinated phosphanes. [38-40] The distances Fe- $\eta^{5}$-Cp (centroid) are very similar in both complexes (1.7153 $\AA$ for complex 1, and 1.7164 $\AA$ for complex 3 ) and in good agreement with the donor/acceptor nature and number of other ligands bound to iron atom. The distances $\mathrm{Fe}-\mathrm{N} \equiv \mathrm{C}$ range from 1.8670 to $1.8865 \AA$ are well within the values expected for this family of compounds and their bond angles present only a slight deviation of the linearity, with values in accordance to those found for related compounds [38-40]. Different spatial orientation of the two isomeric ligands in both complexes can be observed. This fact can have some biological importance since it might determine the way of interaction of each complex with DNA or other biological molecules. In Table 4, the main bond lengths and angles are presented.

\subsection{Electrochemical studies}

In order to obtain an insight on the electron richness of the organometallic fragment and on the coordinated ligands, the electrochemical properties of the ligands L1-L4 and the new iron(II) complexes were studied by cyclic voltammetry in acetonitrile and dichloromethane solutions $\left(1 \times 10^{-3} \mathrm{M}\right)$ using $0.1 \mathrm{M}$ or $0.2 \mathrm{M}$ tetrabutylammonium hexafluorophosphate ( $\mathrm{TBAPF}_{6}$ ) as supporting electrolyte, between the limits imposed by the solvents. The electrochemical data measured for the studied compounds at the scan rate of $0.200 \mathrm{~V} / \mathrm{s}$, are reported in Table 5 and Table 6 . The redox behavior of the ligands L1-L3 was characterized by an irreversible reductive process near $-1.70 \mathrm{~V}$, whereas for the 2,3pyrazinedicarbonitrile ligand (L4) this process is observed at $\sim 1.15 \mathrm{~V}$, for both solvents. The electrochemical responses of the iron(II) compounds 1, 2, 4 and 5 in acetonitrile were characterized by the presence of an irreversible redox process in the positive potential range and two or three reductive processes at negative potentials. This behavior is also expected for compound 3 since its cation is isostructural of compound 2. The cyclic voltammogram of complex $[\mathrm{FeCp}(\mathrm{dppe})(2,3-\mathrm{dcpz})]\left[\mathrm{PF}_{6}\right] 5$ is 
showed on Fig. 5 and typifies the behavior found for all the complexes in this solvent. The irreversible oxidation placed in the range $0.80 \mathrm{e} 0.92 \mathrm{~V}$ can be attributed to the metal centered process $\left(\mathrm{Fe}^{\mathrm{II}} / \mathrm{Fe}^{\mathrm{III}}\right)$. The correspondent reductive wave was observed at $0.62 \mathrm{~V}$ for all the complexes and no changes in this potential were observed at different scan rates. This behavior can be related with an $\mathrm{Fe}^{\mathrm{II}} \rightarrow \mathrm{Fe}^{\mathrm{III}}$ oxidation, leading to the 17 -electron species $[\mathrm{FeCp}(\mathrm{dppe})(\mathrm{L})]^{2+}$, formed on the electrode surface which undergo fast substitution of the cyanoquinoline or pyrazine ligands by an acetonitrile molecule. The formed $\left[\mathrm{FeCp}(\text { dppe })\left(\mathrm{NCCH}_{3}\right)\right]^{+}$species is responsible for the observed reductive process when the scan direction is reverted. Moreover, the presence of a small reductive wave in the free ligand position (Epc $=-.16 \mathrm{~V}$ ) (Fig. 5) confirms the ligand exchange process. This result is consistent with the redox behavior of the isolated complex $\left[\mathrm{FeCp}(\mathrm{dppe})\left(\mathrm{NCCH}_{3}\right)\right]\left[\mathrm{PF}_{6}\right]$ (Fig. 5) studied before in an independent experiment for related monocyclopentadienyliron(II)dppe derivatives [39] where the same electrochemical ligand exchange process was observed. In fact, for complexes $\left[\mathrm{FeCp}(\mathrm{dppe})\left(\mathrm{NC}\left\{\mathrm{SC}_{4} \mathrm{H}_{2}\right\}_{\mathrm{nNO}}\right)\right]\left[\mathrm{PF}_{6}\right]$, the substitution of the thiophene ligands by the acetonitrile solvent was observed during the oxidative process in the electrochemical experiments. The reductive processes found at negative potentials were attributed to ligand-based processes occurring at the coordinated cyanoquinoline (L1 and L2) or pyrazine (L4) ligands, which became easier upon coordination.

The electrochemical response of compounds 1, 2 and 4 in dichloromethane is slightly different. Fig. 6 shows the cyclic voltammogram of complex $\left[\mathrm{Fe}\left(\eta^{5}-\mathrm{C}_{5} \mathrm{H}_{5}\right)(\mathrm{dppe})(3-\mathrm{cq})\right]\left[\mathrm{PF}_{6}\right] 2$ which typifies the electrochemical behavior of complexes 1 and 2 with the cyanoquinoline ligands. No substitution processes involving solvent molecules were observed and the redox behavior is characterized by the presence of a single quasi-reversible process (I) attributed to the $\mathrm{Fe}^{\mathrm{II}} / \mathrm{Fe}^{\mathrm{III}}$ redox pair in the range 0.84$0.90 \mathrm{~V}$ at positive potentials and one or two irreversible reductive waves at negative range (II and III, see Fig. 6) derived from processes occurring at the coordinated cyanoquinoline ligands. Nevertheless, for complex 4 a distinct behavior was observed and only an irreversible metal centered oxidation at 0.66 $\mathrm{V}$ was observed, indicating a complete decomposition process for the complex after iron(II) oxidation. Moreover, the instability in the electrochemical cell of compound 5 did not allow further studies.

\subsubsection{Atomic force microscopy}

Compounds 1e 5 were incubated for $4 \mathrm{~h}$ at $37{ }^{\circ} \mathrm{C}$ in the molar relationship compound:DNA $=1: 2$. The images obtained by AFM are presented in Fig. 7. These images show that all the compounds modify the free DNA forms. In Fig. 7(a) the free pBR322 plasmid DNA shows the usual open and supercoiled forms. The image (b) shows the modifications caused by compound 1 after incubation with pBR322 DNA clearly showing broken chains and a strong interaction of the complex on DNA. In image (c) it can be mainly observed an aggregation of the forms on the mica surface and modifications in the supercoling caused by interaction of compound 2 on pBR322 DNA. Compounds 3 and 4 produce similar effects on DNA (images (d) and (e), respectively): the number of supercoiled forms deposited on the mica has increased. Finally, image (f) reveals that complex 5 causes strong supercoling in some DNA forms and kinks in those forms that remain open. The authors have observed similar effects in compounds with planar ligands which probably intercalate on DNA [41].

\subsubsection{Cytotoxicity of the iron complexes against $H L-60$ cells}

The cytotoxic effect of the iron complexes was examined on human leukemia cancer cells (HL-60) using the MTT assay, a colorimetric determination of cell viability during in vitro treatment with a drug. The assay, developed as an initial stage of drug screening, measures the amount of MTT reduction by 
455 mitochondrial dehydrogenase and assumes that cell viability (corresponding to the reductive activity) is

456 proportional to the production of purple formazan that is measured spectrophotometrically. A low IC50

457 is desired and implies cytotoxicity or antiproliferation at low drug concentrations. All the new $\mathrm{Fe}(\mathrm{II})$

458 complexes were tested, together with cisplatin (CDDP) as a positive control. Cells were exposed to each

459 compound continuously for a $24 \mathrm{~h}$ or a $72 \mathrm{~h}$ period of time and then assayed for growth using the MTT

460 endpoint assay. Table 7 presents the IC 50 values against HL-60 cells. The IC 50 values at $24 \mathrm{~h}$ are lower

461 than that for the reference drug, cisplatin. At $72 \mathrm{~h}$, compounds 2 and 4 show higher IC50 values than

462 cisplatin, although compounds 1, 3 and 5 present an excellent antiproliferative behavior with IC 50 values

463 lower than cisplatin forecasting interesting structureeactivity relationships.

464

465 3.6. Quantification of apoptosis by Annexin V binding and flow cytometry

466 We have also analyzed, by Annexin V-PI flow cytometry, whether complexes 1-5 are able to induce 467 apoptosis in HL-60 cells after $24 \mathrm{~h}$ of incubation at equitoxic concentrations (IC50 values). Annexin V 468 binds phosphatidyl serine residues, which are asymmetrically distributed towards the inner plasma 469 membrane but migrate to the outer plasma membrane during apoptosis [33]. As it can be seen in Table 4708 , complex 3 is able to induce apoptosis death in a $26.21 \%$, close to that of cisplatin. Compounds 1,4 471 and 5, induce cell death by apoptosis in a lower percentage. Complex 2 presents only a discrete 472 percentage of apoptosis at $\mathrm{IC}_{50}$ dose, being the major death process caused by necrosis. 


\section{Conclusions}

A new family of five half sandwich compounds derived from " $\mathrm{Fe}^{\mathrm{II}}\left(\eta_{5}-\mathrm{C}_{5} \mathrm{H}_{5}\right)$ " bearing a coordinated nitrile ligand, which structure comprises one or two N-heteroaromatic rings, has been synthesized and successfully characterized. Spectroscopic evidence shows a strong p-backdonation involving the metal center. X-ray studies for two of these new compounds revealed crystallization in the monoclinic P21/c and monoclinic $\mathrm{P} 21 / \mathrm{n}$ space groups.

In a preliminary approach to evatuate the cytotoxic behavior of these new compounds against cancer cells, some studies were carried out involving human leukemia cancer cells (HL-60) by MTT assay. Also their interaction AFM images with pBR322 DNA plasmid show different behaviors that can be related with the NCL ligand. Indeed, IC50 values together with the apoptosis results show significant differences between the whole series of compounds. There are some main conclusions that can be drawn: i) compound 1, bearing the 2-quinolinecarbonitrile, presents the best cytotoxicity and its AFM image showed the most relevant modifications in pBR322 DNA; ii) structural difference in the position of the nitrile group in compounds 1 and 2 (ortho vs. meta) leads to a decrease on the cytotoxicity (4-fold); iii) comparison of results of compounds 2 and 3 (bearing in both cases the 3-quinolinecarbonitrile ligand) shows that the replacement of $\mathrm{PF}_{6}$ by $\mathrm{CF}_{3} \mathrm{SO}_{3}$ leads to a more cytotoxicity compound and the principal mechanism of death is changed from necrosis to apoptosis; iv) 2-pyrazinecarbonitrile (L3) leads to the less cytotoxic compound (4); and finally v) the introduction of a second nitrile group in L3 leads to a 3fold increase in the cytotoxic behavior (compound 5). The overall results show that after $24 \mathrm{~h}$ of incubation all the compounds are more cytotoxic than cisplatin. Thus, this is a potentially interesting family of compounds to be studied in the frame of anticancer drugs. 
497 ACKNOWLEDGEMENTS

498

499 The authors thank financial support from the Portuguese Foundation for Science and Technology for

500 the projects PEst-OE/QUI/UI0536/2011, PTDC/QUI-QUI/118077/2010, PTDC/QUI501 QUI/101187/2008 and SFRH/BPD/80459/2011 (Andreia Valente's postdoctoral scholarship) and 502 Spanish Ministry of Ciencia e Innovacion, projects CTQ2008-02064 and BIO2010-22321-C02-01. 
505

506

507

508

509

510

511

512

513

514

515

516

517

518

519

520

521

522

523

524

525

526

527

528

529

530

531

532

533

534

535

536

537

538

539

\section{References}

[1] H. Köpf, P. Köpf-Maier, Angew. Chem. 91 (1979) 509.

[2] T.M. Klapötke, H. Köpf, I.C. Tornieporth-Oetting, P.S. White, Organometallics 13 (1994) $3628 \mathrm{e} 3633$.

[3] C.V. Christodoulou, A. Eliopoulos, A. Young, L. Hodgkins, D.R. Ferry, D.J. Kerr, Br. J. Cancer 77 (1998) 2088e2097.

[4] P. Köpf-Maier, Anticancer Res. 19 (1999) 493e504.

[5] K. Kröer, U.R. Kleeberg, K. Mross, L. Edler, D.K. Hossfeld, Onkologie 23 (2000) 60e62.

[6] K. Mross, P. Robben-Bathe, L. Edler, J. Baumgart, W.E. Berdel, H. Fiebig, C. Unger, Onkologie 23 (2000) 576e 579.

[7] L.V. Popova, V.N. Babin, Y.A. Belousov, Y.S. Nekrasov, A.E. Snegireva, N.P. Borodina, G.M. Shaposhnikova, O.B. Bychenko, P.M. Raevskii, Appl. Organometal. Chem. 7 (1993) 85e94.

[8] P. Köpf-Maier, H. Köpf, E.W. Neuse, J. Cancer Res. Clin. Oncol. 108 (1984) 336e 340.

[9] W. Henderson, S.R. Alley, Inorg. Chim. Acta 322 (2001) 106e112.

[10] P. Köpf-Maier, H. Köpf, Chem. Rev. 87 (1987) 1137e1152.

[11] G. Gasser, I. Ott, N. Metzler-Nolte, J. Med. Chem. 54 (2011) 3e25.

[12] R.E. Morris, R.E. Aird, P.D.S. Murdoch, H. Chen, J. Cummings, N.D. Hughes, S. Parsons, A. Parkin, G. Boyd, D. Jodrell, P.J. Sadler, J. Med. Chem. 44 (2001) $3616 e 3621$.

[13] R.E. Aird, J. Cummings, M. Muir, R.E. Morris, H. Chen, P.J. Sadler, Br. J. Cancer 86 (2002) $1652 \mathrm{e} 1657$.

[14] S.J. Dougan, M. Melchart, A. Habtermariam, S. Parsons, P.J. Sadler, Inorg. Chem. 45 (2006) $10882 \mathrm{e} 10894$.

[15] F. Wang, J. Bella, J.A. Parkinson, P.J. Sadler, J. Biol. Inorg. Chem. 10 (2005) 147e 155.

[16] H. Chen, J.A. Parkinson, O. Novakova, J. Bella, F. Wang, A. Dawson, R. Gould, S. Parsons, V. Brabec, P.J. Sadler, Proc. Natl. Acad. Sci. 100 (2003) 14623e 14628.

[17] V. Marini, P. Christofis, O. Novakova, J. Kasparkova, N. Farrell, V. Brabec, Nucleic Acids Res. 33 (2005) 5819e5828.

[18] C. Scolaro, A. Bergamo, L. Brescacin, R. Delfino, M. Cocchietto, G. Laurenczy, T.J. Geldbach, G. Sava, P.J. Dyson, J. Med. Chem. 48 (2005) 4161e4171.

[19] M.H. Garcia, T.S. Morais, P. Florindo, M.F.M. Piedade, V. Moreno, C. Ciudad, V. Noe, J. Inorg. Biochem. 103 (2009) 354.

[20] V. Moreno, J. Lorenzo, F.X. Aviles, M.H. Garcia, J. Ribeiro, T.S. Morais, P. Florindo, M.P. Robalo, Bioinorg. Chem. Appl. (2010), 11, Article ID 936834.

[21] V. Moreno, M. Font-Bardia, T. Calvet, J. Lorenzo, F.X. Avilés, M.H. Garcia, T.S. Morais, A. Valente, M.P. Robalo, J. Inorg. Biochem. 105 (2011) 241. 
[22] T.S. Morais, T.J.L. Silva, F. Marques, M.P. Robalo, F. Avecilla, P.J.A. Madeira, P.J.G. Mendes, I. Santos, M.H. Garcia, J. Inorg. Biochem. 114 (2012) 65e74.

[23] A.I. Tomaz, T. Jakusch, T.S. Morais, F. Marques, R.F. de Almeida, F. Mendes, E.A. Enyedy, I. Santos, J.C. Pessoa, T. Kiss, M.H. Garcia, J. Inorg. Biochem. 117 (2012) 261e269.

[24] T.S. Morais, F. Santos, L. Côrte-Real, F. Marques, M.P. Robalo, P.J.A. Madeira, M.H. Garcia, J. Inorg. Biochem. 122 (2013) 8e17.

[25] A.R. Timerbaev, C.G. Hartinger, S.S. Aleksenko, B.K. Keppler, Chem. Rev. 106 (2006) $2224 \mathrm{e} 2248$.

[26] A.C. Gonçalves, T.S. Morais, M.P. Robalo, F. Marques, F. Avecilla, C.P. Matos, I. Santos, A.I. Tomaz, M.H. Garcia, J. Inorg. Biochem. 129 (2013) 1 e8.

[27] D.D. Perrin, W.L.F. Amarego, D.R. Perrin, Purification of Laboratory Chemicals second ed., Pergamon, New York, 1980, pp. 65e371.

[28] M.L.H. Green, R. Whiteley, J. Chem. Soc. A (1971) 1943.

[29] G.M. Sheldrick, A Program for Automatic Solution of Crystal Structure, Univer Goettingen, Germany, 1997.

[30] G.M. Sheldrick, A Program for Crystal Structure Refinement, Univer Goettingen, Germany, 1994.

[31] International Tables of X-Ray Crystallography, vol. IV, Kynoch Press, 1974, pp. 99e100 and 149 .

[32] N.G. Conelly, W.E. Geiger, Chem. Rev. 96 (1996) 877e910.

[33] I. Vermes, C. Haanen, H. Steffens-Nakken, C. Reutelingsperger, J. Immunol. Meth. 184 (1995) $39 \mathrm{e} 51$.

[34] G.S. Ashby, M.I. Bruce, I.B. Tomkins, R.C. Walli, Aust. J. Chem. 32 (1979) 1003e 1016.

[35] M.H. Garcia, P. Florindo, M.F.M. Piedade, M.T. Duarte, M.P. Robalo, J. Heck, C. Wittenburg, J. Holtmann, E. Licandro, J. Organomet. Chem. 693 (2008) 2987e2999.

[36] A.R. Dias, M.H. Garcia, J.C. Rodrigues, M.L.H. Green, K.K. Lai, S.M. Klueber, J. Organomet. Chem. 475 (1994) 241.

[37] A. Valente, S. Royer, M. Narendra, T.J.L. Silva, P.J.G. Mendes, M.P. Robalo, M. Abreu, J. Heck, M.H. Garcia, J. Organomet. Chem. 736 (2013) 42 e49.

[38] M.H. Garcia, M.P. Robalo, A.R. Dias, M.F.M. Piedade, A. Galvão, M.T. Duarte, W. Wenseleers, E. Goovaerts, J. Organomet. Chem. 619 (2001) 252.

[39] R.L. Cordiner, D. Albesa-Jové, R.L. Roberts, J.D. Farmer, H. Puschmann, D. Corcoran, A.E. Goeta, J.A.K. Howard, P.J. Low, J. Organomet. Chem. 690 (2005) 4908.

[40] Maria Helena Garcia, Pedro Florindo, Maria de Fátima M. Piedade, Stefano Maiorana, Emanuela Licandro, Polyhedron 28 (2009) 621e629.

[41] X. Riera, V. Moreno, C.J. Ciudad, V. Noe, M. Font-Bardia, X. Solans, Bioinorg. Chem. Appl. (2007) 1e15. Article ID 98732. 
591 592

593

594 595

596

597

598

599

600

601

602

603

604

\section{Legends to figures}

Scheme 1. Reaction scheme for the synthesis of the new Fe(II) complexes and the ligand structures numbered for NMR purposes

Figure 1. Electronic spectra of $[\mathrm{FeCp}(\mathrm{dppe})(\mathrm{L})] \mathrm{p}(1 \mathrm{e} 5)$ in dichloromethane solutions:- $1 ;----2 ; \cdots \cdots 3$; $--4 ;-\cdot-\cdot 5$.

Figure 2. Electronic spectra of $\left[\mathrm{Fe}\left(\eta^{5}-\mathrm{C}_{5} \mathrm{H}_{5}\right)(\mathrm{dppe})(2-\mathrm{cq})\right]\left[\mathrm{PF}_{6}\right] 1$ in dichloromethane $(\cdots \cdots)$ and dimethylsulfoxide (-) showing solvatochromism of the MLCT transition.

Figure 3. ORTEP drawing of $\left[\mathrm{Fe}\left(\eta^{5}-\mathrm{C}_{5} \mathrm{H}_{5}\right)(\mathrm{dppe})(2-\mathrm{cq})\right]\left[\mathrm{PF}_{6}\right] 1$ with atomic numbering scheme.

Figure 4. ORTEP drawing of $\left[\mathrm{Fe}\left(\eta^{5}-\mathrm{C}_{5} \mathrm{H}_{5}\right)(\mathrm{dppe})(3-\mathrm{cq})\right]\left[\mathrm{CF}_{3} \mathrm{SO}_{3}\right] 3$ with atomic numbering scheme.

Figure 5. Cyclic voltammetry of complexes $\left[\mathrm{Fe}\left(\eta^{5}-\mathrm{C}_{5} \mathrm{H}_{5}\right)(\mathrm{dppe})(2,3-\mathrm{dcpz})\right][\mathrm{PF} 6] 5(-)$ and $\left[\mathrm{Fe}\left(\eta^{5}-\right.\right.$ $\left.\left.\mathrm{C}_{5} \mathrm{H}_{5}\right)(\mathrm{dppe})(\mathrm{NCMe})\right]\left[\mathrm{PF}_{6}\right]\left(--\mathrm{-} \mathrm{-}^{-}\right.$in acetonitrile $(\mathrm{v}=200 \mathrm{mV} / \mathrm{s})$.

Figure 6. Cyclic voltammetry of complex $\left[\mathrm{Fe}\left(\eta^{5}-\mathrm{C}_{5} \mathrm{H} 5\right)(\mathrm{dppe})(3-\mathrm{cq})\right][\mathrm{PF} 6] 2(-)$ and 3-cq ligand (- - - -) in dichloromethane ( $\mathrm{v}=200 \mathrm{mV} / \mathrm{s})$.

Figure 7. AFM images of (a) plasmid pBR322 DNA and plasmid pBR322 DNA incubated with complex (b) $\left[\mathrm{Fe}\left(\eta^{5}-\mathrm{C}_{5} \mathrm{H}_{5}\right)(\mathrm{dppe})(2-\mathrm{cq})\right]\left[\mathrm{PF}_{6}\right] \quad 1, \quad$ (c) $\left[\mathrm{Fe}\left(\eta^{5}-\mathrm{C}_{5} \mathrm{H}_{5}\right)(\mathrm{dppe})(3-\mathrm{cq})\right][\mathrm{PF} 6] \quad 2, \quad$ (d) $\left[\mathrm{Fe}\left(\eta^{5}-\right.\right.$ $\left.\left.\mathrm{C}_{5} \mathrm{H}_{5}\right)(\mathrm{dppe})(3-\mathrm{cq})\right]\left[\mathrm{CF}_{3} \mathrm{SO}_{3}\right] 3$, (e) $\left[\mathrm{Fe}\left(\eta^{5}-\mathrm{C}_{5} \mathrm{H}_{5}\right)(\mathrm{dppe})(\mathrm{cpz})\right]\left[\mathrm{PF}_{6}\right] 4$ and (f) $\left[\mathrm{Fe}\left(\eta^{5}-\mathrm{C}_{5} \mathrm{H}_{5}\right)(\mathrm{dppe})(2,3-\right.$ dcpz)][PF6] 5. 
605 Table 1. ${ }^{1} \mathrm{H}$ NMR data for the ligands (L1eL4) and the complexes (1e5), in (CD3) $2 \mathrm{CO}$.

606

607

\begin{tabular}{llllllllll}
\hline & $\mathbf{H}_{\mathbf{3}}$ & $\mathbf{H}_{\mathbf{4}}$ & $\mathbf{H}_{\mathbf{5}}$ & $\mathbf{H}_{\mathbf{6}}$ & $\mathbf{H}_{\mathbf{7}}$ & $\mathbf{H}_{\mathbf{8}}$ & $\mathbf{H}_{\mathbf{9}}$ & $\mathbf{H}_{\mathbf{1 0}}$ & $\mathbf{C p}$ \\
\hline $\mathbf{L} \mathbf{1}$ & - & 8.13 & 7.93 & 7.81 & 8.13 & - & 7.95 & 8.63 & - \\
$\mathbf{1}$ & - & 7.96 & 7.73 & 7.88 & 7.96 & - & 6.78 & 8.30 & 4.75 \\
$\mathbf{L} \mathbf{2}$ & 9.11 & - & 8.14 & 7.78 & 7.98 & 8.11 & - & 8.92 & - \\
$\mathbf{2}$ & 7.92 & - & 8.00 & 7.71 & 7.92 & 7.85 & - & 7.68 & 4.73 \\
$\mathbf{3}$ & 7.92 & - & 8.01 & 7.71 & 7.92 & 7.87 & - & 7.71 & 4.74 \\
$\mathbf{L} \mathbf{3}$ & 9.13 & 8.95 & 8.84 & - & - & - & - & - & - \\
$\mathbf{4}$ & 7.88 & 8.67 & 8.55 & - & - & - & - & - & 4.75 \\
$\mathbf{L} \boldsymbol{4}$ & - & 9.14 & 9.14 & - & - & - & - & - & - \\
$\mathbf{5}$ & - & 8.83 & 8.82 & - & - & - & - & - & 4.86 \\
\hline
\end{tabular}

608

609

610 
611 Table 2. Optical spectra data for complexes $\left[\mathrm{Fe}\left(\eta^{5}-\mathrm{C}_{5} \mathrm{H}_{5}\right)(\mathrm{dppe})(\mathrm{L})\right]^{+}(1-5)$ in dichloromethane and 612 dimethylsulfoxide solutions. Sh: shoulder.

613

\begin{tabular}{lll}
\hline Compound & \multicolumn{2}{l}{$\lambda_{\max }(\mathrm{nm})\left(\varepsilon \mathrm{M}^{-1} \mathrm{~cm}^{-1}\right)$} \\
\cline { 2 - 3 } & $\mathrm{CH}_{2} \mathrm{Cl}_{2}$ & DMSO \\
\hline$\left[\mathrm{Fe}\left(\eta^{5}-\mathrm{C}_{5} \mathrm{H}_{5}\right)(\mathrm{dppe})(2-\mathrm{cq})\right]\left[\mathrm{PF}_{6}\right] \mathbf{1}$ & $240(73,195)$ & - \\
& $385(6049)$ & $392(\mathrm{Sh})$ \\
{$\left[\mathrm{Fe}\left(\eta^{5}-\mathrm{C}_{5} \mathrm{H}_{5}\right)(\mathrm{dppe})(3-\mathrm{cq})\right]\left[\mathrm{PF}_{6}\right] \mathbf{2}$} & $441(6893)$ & $455(7669)$ \\
& $239(75,639)$ & - \\
& $275(\mathrm{Sh})$ & - \\
{$\left[\mathrm{Fe}\left(\eta^{5}-\mathrm{C}_{5} \mathrm{H}_{5}\right)(\mathrm{dppe})(3-\mathrm{cq})\right]\left[\mathrm{CF}_{3} \mathrm{SO}_{3}\right] \mathbf{3}$} & $376(7169)$ & $386(6559)$ \\
& $429(5136)$ & $442(7292)$ \\
{$\left[\mathrm{Fe}\left(\eta^{5}-\mathrm{C}_{5} \mathrm{H}_{5}\right)(\mathrm{dppe})(\mathrm{cpz})\right]\left[\mathrm{PF}_{6}\right] \mathbf{4}$} & $239(51,562)$ & - \\
& $278(\mathrm{Sh})$ & - \\
{$\left[\mathrm{Fe}\left(\eta^{5}-\mathrm{C}_{5} \mathrm{H}_{5}\right)(\mathrm{dppe})(2,3-\mathrm{cpz})\right]\left[\mathrm{PF}_{6}\right] \mathbf{5}$} & $369(3559)$ & $386(4380)$ \\
& $428(2371)$ & $442(4798)$ \\
& $264(20,282)$ & - \\
& $388(\mathrm{Sh})$ & - \\
& $445(2895)$ & $446(5225)$ \\
& $266(12,201)$ & - \\
& $521(2521)$ & $512(5710)$ \\
\hline
\end{tabular}

615

616

617 
618 Table 3 Crystal data and structure refinement for $\left[\mathrm{Fe}\left(\eta^{5}-\mathrm{C}_{5} \mathrm{H}_{5}\right)(\mathrm{dppe})(2-\mathrm{cq})\right]\left[\mathrm{PF}_{6}\right] 1$ and $\left[\mathrm{Fe}\left(\eta^{5}-\right.\right.$ $\left.619 \mathrm{C}_{5} \mathrm{H}_{5}\right)($ dppe $\left.)(3-\mathrm{cq})\right]\left[\mathrm{CF}_{3} \mathrm{SO}_{3}\right] 3$.

620

\begin{tabular}{|c|c|c|}
\hline Empirical formula & $\mathrm{C}_{41} \mathrm{H}_{35} \mathrm{~F}_{6} \mathrm{Fe} \mathrm{N} \mathrm{N}_{2} \mathrm{P}_{3}$ & $\mathrm{C}_{42} \mathrm{H}_{35} \mathrm{~F}_{3} \mathrm{Fe} \mathrm{N}_{2} \mathrm{O}_{3} \mathrm{P}_{2} \mathrm{~S}$ \\
\hline Formula weight & 818.47 & 822.57 \\
\hline$T(\mathrm{~K})$ & $293(2)$ & $293(2)$ \\
\hline Wavelength & $0.71073 \AA$ & $0.71073 \AA$ \\
\hline Crystal system & Monoclinic & Monoclinic \\
\hline Space group & $\mathrm{P} 2_{1} / n$ & $\mathrm{P} 2{ }_{1} / c$ \\
\hline$a(\hat{\mathrm{A}})$ & $15.927(6)$ & $a=10.962(5)$ \\
\hline$b(\AA)$ & $11.251(4)$ & $b=17.000(6)$ \\
\hline$c(\AA)$ & $21.013(3)$ & $c=20.986(7)$ \\
\hline$\alpha\left({ }^{\circ}\right)$ & 90 & 90 \\
\hline$\beta\left(^{\circ}\right)$ & $95.32(2)$ & $\beta=102.57(2)$ \\
\hline$\gamma\left({ }^{\circ}\right)$ & 90 & 90 \\
\hline$V\left(\AA^{3}\right)$ & $3749(2)$ & $3817(3)$ \\
\hline $\mathrm{z}$ & 4 & 4 \\
\hline$D_{c}\left(\mathrm{Mg} / \mathrm{m}^{3}\right)$ & 1.450 & 1.431 \\
\hline $\begin{array}{l}\text { Absorption } \\
\text { coefficient }\left(\mathrm{mm}^{-1}\right)\end{array}$ & 0.593 & 0.591 \\
\hline$F(000)$ & 1680 & 1696 \\
\hline $\begin{array}{l}\text { Theta range for } \\
\text { data collection }\left({ }^{\circ}\right)\end{array}$ & $1.54-28.39$ & $2.59-32.32$ \\
\hline Limiting indices & $\begin{array}{l}-18 \leq h \leq 19,-12 \\
\leq k \leq 13,-25 \leq l \leq 26\end{array}$ & $\begin{array}{l}-13 \leq h \leq 15,-23 \\
\leq k \leq 23,-27 \leq l \leq 28\end{array}$ \\
\hline $\begin{array}{l}\text { Reflections } \\
\text { collected/unique }\end{array}$ & $\begin{array}{l}20,388 / 7170 \\
[R \text { (int })=0.0265]\end{array}$ & $\begin{array}{l}29,982 / 9989 \\
{[R \text { (int) }=0.0387]}\end{array}$ \\
\hline $\begin{array}{l}\text { Completeness to } \\
\text { theta }=25.00\left(^{\circ}\right)\end{array}$ & $93.0 \%$ & $98.4 \%$ \\
\hline Absorption correction & Empirical & Empirical \\
\hline Max. and min. transmission & 0.94 and 0.93 & 0.94 and 0.93 \\
\hline Refinement method & $\begin{array}{l}\text { Full-matrix } \\
\text { least-squares on } F^{2}\end{array}$ & $\begin{array}{l}\text { Full-matrix } \\
\text { least-squares on } F^{2}\end{array}$ \\
\hline $\begin{array}{l}\text { Data/restraints/ } \\
\text { parameters }\end{array}$ & $7170 / 49 / 514$ & $9989 / 53 / 646$ \\
\hline Goodness-of-fit on $F^{2}$ & 1.062 & 1.149 \\
\hline Final $R$ indices $[I>2(I)]$ & $\begin{array}{l}R 1=0.0498 \\
w R 2=0.1520\end{array}$ & $\begin{array}{l}R 1=0.0419 \\
w R 2=0.1062\end{array}$ \\
\hline $\mathrm{R}$ índices (all data) & $\begin{array}{l}R 1=0.0499 \\
w R 2=0.1521\end{array}$ & $\begin{array}{l}R 1=0.0446 \\
w R 2=0.1086\end{array}$ \\
\hline Largest diff. peak/hole $\left(\mathrm{e} \AA^{3}\right)$ & 0.517 and -1.720 & 0.576 and -0.339 \\
\hline
\end{tabular}


625 Table 4 Selected bond lenghts and torsion angles for $\left[\mathrm{Fe}\left(\eta^{5}-\mathrm{C}_{5} \mathrm{H}_{5}\right)(\mathrm{dppe})(2-\mathrm{cq})\right][\mathrm{PF} 6] 1$ and $\left[\mathrm{Fe}\left(\eta^{5}-\right.\right.$ $\left.\left.626 \mathrm{C}_{5} \mathrm{H}_{5}\right)(\mathrm{dppe})(3-\mathrm{cq})\right]\left[\mathrm{CF}_{3} \mathrm{SO}_{3}\right] 3$.

627

\begin{tabular}{llll}
\hline Compound 1 & \multicolumn{3}{l}{ Compound 3 } \\
\hline Bond lenght $(\AA)$ & & & \\
$\mathrm{Fe}-\mathrm{P} 1$ & $2.2263(9)$ & $2.2226(7)$ & $\mathrm{Fe}-\mathrm{P} 1$ \\
$\mathrm{Fe}-\mathrm{P} 2$ & $2.2211(9)$ & $2.2148(8)$ & $\mathrm{Fe}-\mathrm{P} 2$ \\
$\mathrm{Fe}-\mathrm{N} 1$ & $1.8670(2)$ & $1.8865(14)$ & $\mathrm{Fe}-\mathrm{N} 2$ \\
$\mathrm{Fe}-\mathrm{Cp}$ & $1.7153(17)$ & $1.7164(12)$ & $\mathrm{Fe}-\mathrm{Cp}$ \\
Angles $\left({ }^{\circ}\right)$ & & & \\
$\mathrm{N}(1)-\mathrm{Fe}-\mathrm{C}(1)$ & $91.01(12)$ & $127.03(7)$ & $\mathrm{N}(2)-\mathrm{Fe}-\mathrm{C}(11)$ \\
$\mathrm{N}(1)-\mathrm{Fe}-\mathrm{C}(5)$ & $91.95(12)$ & $155.73(6)$ & $\mathrm{N}(2)-\mathrm{Fe}-\mathrm{C}(15)$ \\
$\mathrm{N}(1)-\mathrm{Fe}-\mathrm{C}(2)$ & $123.44(13)$ & $92.08(8)$ & $\mathrm{N}(2)-\mathrm{Fe}-\mathrm{C}(12)$ \\
$\mathrm{N}(1)-\mathrm{Fe}-\mathrm{C}(3)$ & $155.94(11)$ & $89.59(7)$ & $\mathrm{N}(2)-\mathrm{Fe}-\mathrm{C}(13)$ \\
$\mathrm{N}(1)-\mathrm{Fe}-\mathrm{C}(4)$ & $125.74(12)$ & $121.96(7)$ & $\mathrm{N}(2)-\mathrm{Fe}-\mathrm{C}(14)$ \\
$\mathrm{N}(1)-\mathrm{Fe}-\mathrm{P}(2)$ & $90.02(8)$ & $90.07(5)$ & $\mathrm{N}(2)-\mathrm{Fe}-\mathrm{P}(2)$ \\
$\mathrm{N}(1)-\mathrm{Fe}-\mathrm{P}(1)$ & $91.76(7)$ & $92.64(5)$ & $\mathrm{N}(2)-\mathrm{Fe}-\mathrm{P}(1)$ \\
$\mathrm{P}(2)-\mathrm{Fe}-\mathrm{P}(1)$ & $87.11(3)$ & $86.93(3)$ & $\mathrm{P}(2)-\mathrm{Fe}-\mathrm{P}(1)$ \\
$\mathrm{Cp}-\mathrm{Fe}-\mathrm{N}(1)$ & 120.79 & 120.40 & $\mathrm{Cp}-\mathrm{Fe}-\mathrm{N}(2)$ \\
$\mathrm{Cp}-\mathrm{Fe}-\mathrm{P}(1)$ & 128.39 & 128.39 & $\mathrm{Cp}-\mathrm{Fe}-\mathrm{P}(1)$ \\
$\mathrm{Cp}-\mathrm{Fe}-\mathrm{P}(2)$ & 127.28 & 127.28 & $\mathrm{Cp}-\mathrm{Fe}-\mathrm{P}(2)$ \\
\hline
\end{tabular}


630 Table 5. Electrochemical data for complexes $\left[\mathrm{Fe}\left(\eta^{5}-\mathrm{C}_{5} \mathrm{H}_{5}\right)(\mathrm{dppe}) \mathrm{L}\right][\mathrm{PF} 6](1-5)$ in acetonitrile at scan 631 rate of $200 \mathrm{mV} \mathrm{s}^{-1}$.

632

\begin{tabular}{llllll}
\hline & $E_{\mathrm{pa}}(\mathrm{V})$ & $E_{\mathrm{pc}}(\mathrm{V})$ & $E_{1 / 2}(\mathrm{~V})$ & $E_{\mathrm{pa}}-E_{\mathrm{pc}}(\mathrm{mV})$ & $I_{\mathrm{c}} / I_{\mathrm{a}}$ \\
\hline $\mathbf{L} 1$ & - & -1.76 & - & - & - \\
$\mathbf{L} 2$ & - & -1.75 & - & - & - \\
$\mathbf{L} 3$ & - & -1.67 & - & - & - \\
$\mathbf{L} \mathbf{4}$ & - & -1.16 & - & - & - \\
$\mathbf{1}$ & 0.81 & - & - & - & - \\
& - & 0.62 & - & - & - \\
& - & -1.42 & - & - & - \\
& -1.60 & -1.69 & -1.65 & 90 & 0.9 \\
$\mathbf{2}$ & $\mathbf{0 . 8 0}$ & - & - & - & - \\
& - & 0.62 & - & - & - \\
& - & -1.45 & - & - & - \\
& - & -1.70 & - & - & - \\
$\mathbf{4}$ & $\mathbf{0 . 8 9}$ & - & - & - & - \\
& - & 0.62 & - & - & - \\
& - & -1.36 & - & - & - \\
& - & -1.67 & - & - & - \\
$\mathbf{5}$ & 0.92 & - & - & - & - \\
& - & 0.62 & - & - & - \\
& - & -1.07 & - & - & - \\
& - & -1.16 & - & - & - \\
& - & -1.70 & - & - & \\
\hline
\end{tabular}


635 Table 6. Electrochemical data for complexes $\left[\mathrm{Fe}\left(\eta^{5}-\mathrm{C}_{5} \mathrm{H}_{5}\right)(\mathrm{dppe}) \mathrm{L}\right][\mathrm{PF} 6](1 \mathrm{e} 6)$ in dichloromethane at 636 scan rate of $200 \mathrm{mV} \mathrm{s}^{-1}$.

637

\begin{tabular}{llllll}
\hline & $E_{\mathrm{pa}}(\mathrm{V})$ & $E_{\mathrm{pc}}(\mathrm{V})$ & $E_{1 / 2}(\mathrm{~V})$ & $E_{\mathrm{pa}}-E_{\mathrm{pc}}(\mathrm{mV})$ & $I_{\mathrm{c}} / I_{\mathrm{a}}$ \\
\hline $\mathbf{L} 1$ & - & -1.68 & - & - & - \\
$\mathbf{L} 2$ & - & -1.70 & - & - & - \\
$\mathbf{L} 3$ & - & - & - & - & - \\
$\mathbf{1}$ & 0.95 & 0.84 & 0.90 & 110 & 1.0 \\
& - & -1.43 & - & - & - \\
$\mathbf{2}$ & 0.88 & 0.81 & 0.84 & 75 & 1.0 \\
& - & -1.45 & - & - & - \\
& - & -1.71 & - & - & - \\
$\mathbf{4}$ & 0.66 & 0.44 & - & - & - \\
\hline
\end{tabular}

638

639

640

641

642 
643 Table 7. IC50 values of iron compounds (1e5) and cisplatin against HL-60 cells.

\begin{tabular}{lll}
\hline Complex & $\mathrm{IC}_{50}(\mu \mathrm{M}) 24 \mathrm{~h}$ & $\mathrm{IC}_{50}(\mu \mathrm{M}) 72 \mathrm{~h}$ \\
\hline$[\mathrm{FeCp}(\mathrm{dppe})(2-\mathrm{cq})]\left[\mathrm{PF}_{6}\right] \mathbf{1}$ & $2.73 \pm 1.85$ & $0.77 \pm 0.22$ \\
{$[\mathrm{FeCp}(\mathrm{dppe})(3-\mathrm{cq})]\left[\mathrm{PF}_{6}\right] \mathbf{2}$} & $3.71 \pm 0.23$ & $3.13 \pm 0.19$ \\
{$[\mathrm{FeCp}(\mathrm{dppe})(3-\mathrm{cq})]\left[\mathrm{CF}_{3} \mathrm{SO}_{3}\right] \mathbf{3}$} & $9.79 \pm 3.11$ & $1.01 \pm 0.57$ \\
{$[\mathrm{FeCp}(\mathrm{dppe})(\mathrm{cpz})]\left[\mathrm{PF}_{6}\right] \mathbf{4}$} & $7.92 \pm 1.37$ & $5.08 \pm 0.41$ \\
{$[\mathrm{FeCp}(\mathrm{dppe})(2,3-\mathrm{dcpz})]\left[\mathrm{PF}_{6}\right] \mathbf{5}$} & $1.97 \pm 0.37$ & $1.20 \pm 0.47$ \\
$\mathrm{CDDP}$ & $15.61 \pm 1.15$ & $2.15 \pm 0.1$ \\
\hline
\end{tabular}

644

645

646

647 
648 Table 8. Percentage of HL-60 cells in each state after treatment with complexes 1e5 at IC50 649 concentration for $24 \mathrm{~h}$ of incubation.

650

651

\begin{tabular}{llccl}
\hline $\begin{array}{l}\text { Treatment } \\
\left(\mathrm{IC}_{50} 24 \mathrm{~h}, \mu \mathrm{M}\right)\end{array}$ & $\begin{array}{l}\text { \% vital } \\
\text { cells }(R 1)\end{array}$ & $\begin{array}{l}\text { \% apoptotic } \\
\text { cells }(R 2)\end{array}$ & $\begin{array}{l}\text { \% dead } \\
\text { cells }(R 3)\end{array}$ & $\begin{array}{l}\text { \% damaged } \\
\text { cells }(R 4)\end{array}$ \\
\hline Control & 92.44 & 4.78 & 2.59 & 0.19 \\
CDDP $(15.6)$ & 60.93 & 33.06 & 4.94 & 1.06 \\
$\mathbf{1}(2.73)$ & 71.84 & 19.39 & 8.19 & 0.57 \\
$\mathbf{2}(3.71)$ & 62.86 & 9.68 & 28.50 & 1.23 \\
$\mathbf{3}(9.79)$ & 62.88 & 26.21 & 9.63 & 1.27 \\
$\mathbf{4}(7.92)$ & 67.91 & 12.48 & 18.95 & 0.66 \\
$\mathbf{5}(1.2)$ & 69.95 & 15.82 & 13.98 & 0.25 \\
\hline
\end{tabular}

652 
Scheme 1.

654
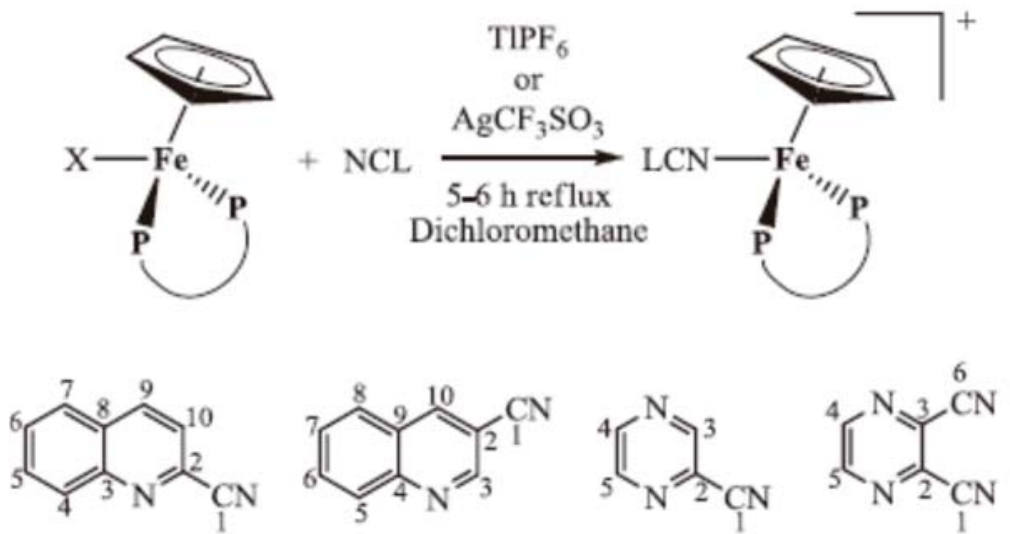

$$
\begin{gathered}
\multicolumn{1}{c}{\begin{array}{c}
\mathrm{L} 1 \\
(2-\mathrm{cq})
\end{array}} \\
\text { Complexes: } \\
\text { 1: } \mathrm{L} 1 ; \mathrm{PF}_{6}^{-} \\
\text {2.: } \mathrm{L} 2_{\mathrm{PF}_{6}^{-}}^{-} \\
\text {느: } \mathrm{L}_{2} ; \mathrm{CF}_{3} \mathrm{SO}_{3}^{-}
\end{gathered}
$$

\section{Complexes:}$$
\text { L2 }
$$$$
\text { L3 }
$$$$
\text { (cpz) }
$$$$
\underset{\text { (2,3-depz) }}{\text { L4 }}
$$

1: $\mathrm{L} 1 ; \mathrm{PF}_{6}{ }^{-}$

2: $\mathrm{L} 2$; $\mathrm{PF}_{6}^{-}$

4: $\mathrm{L} 3 ; \mathrm{PF}_{6}{ }^{-}$

655

5: $\mathrm{L} 4 ; \mathrm{PF}_{6}{ }^{-}$

656

657 
660

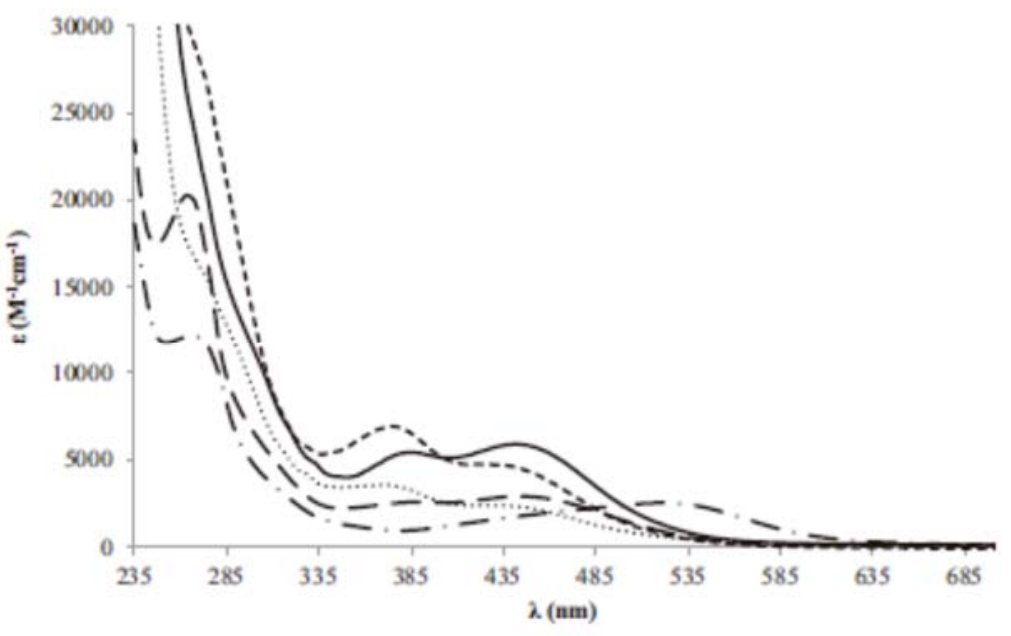

661

Complex 1 ----Complex 2 ....... Complex 3 - Complex $4-$ Complex 5

662

663

664 
666

667

668

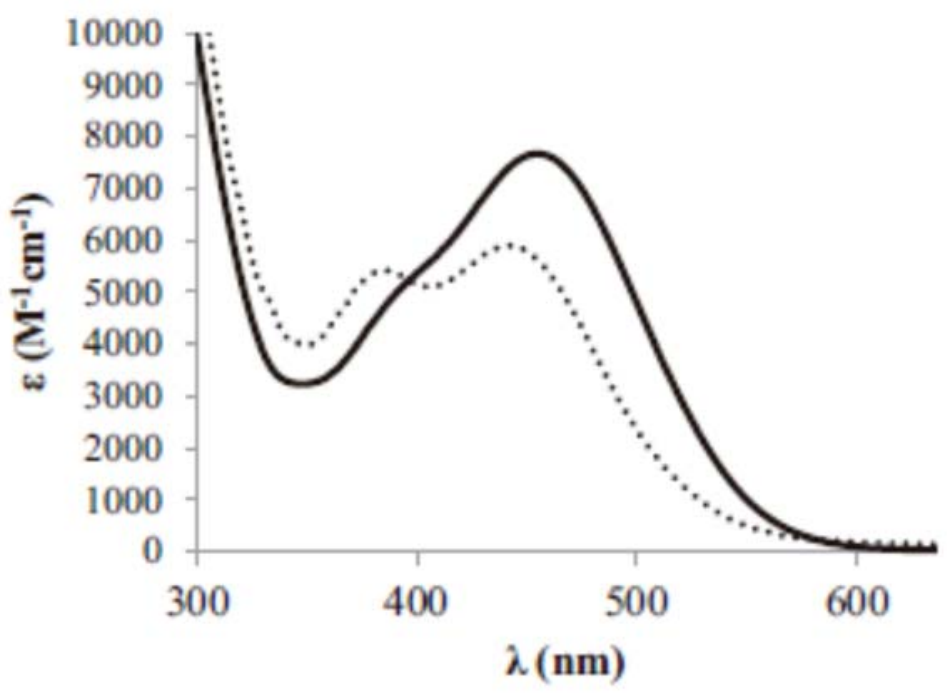


671

672

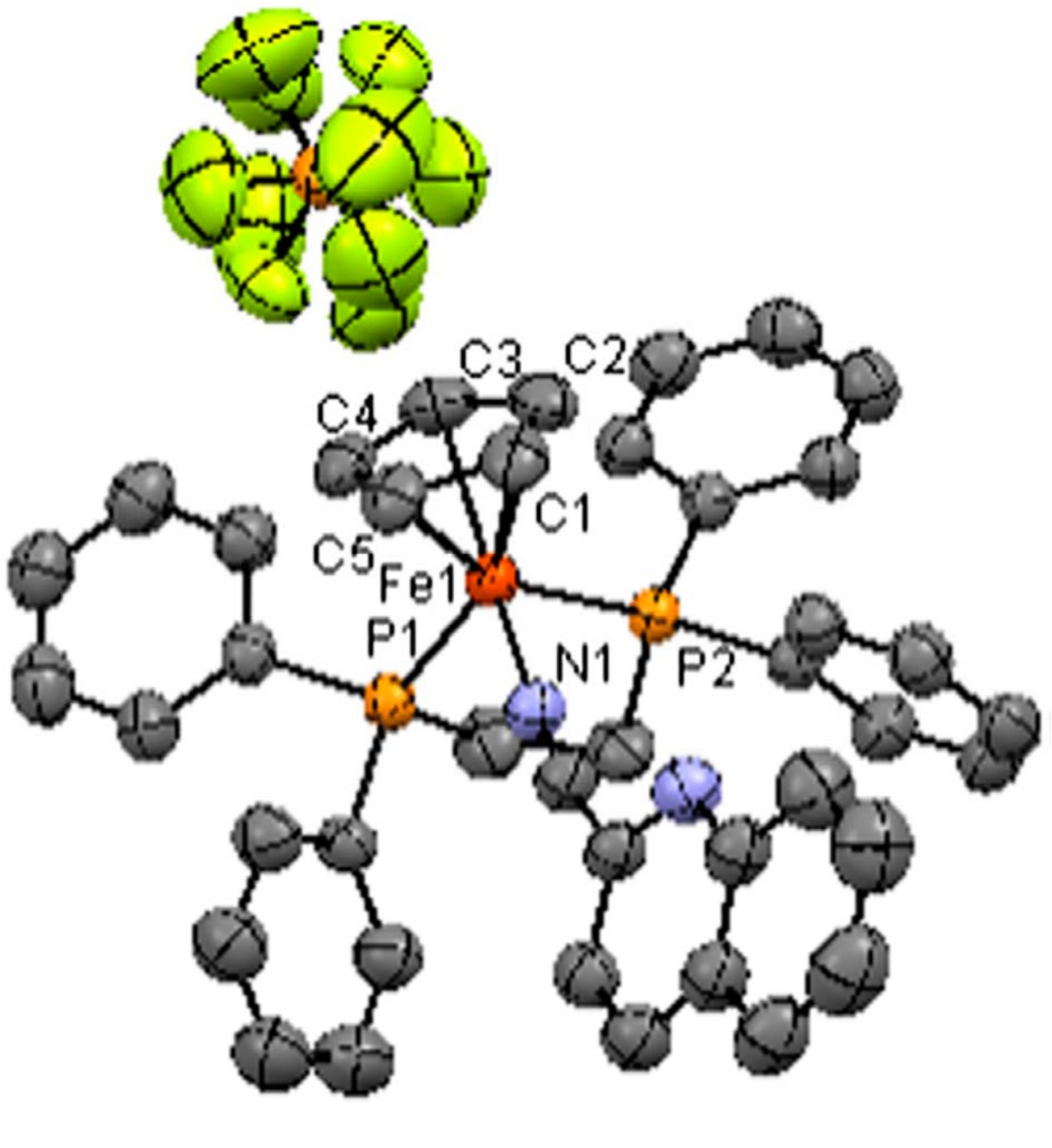

674 
676

677
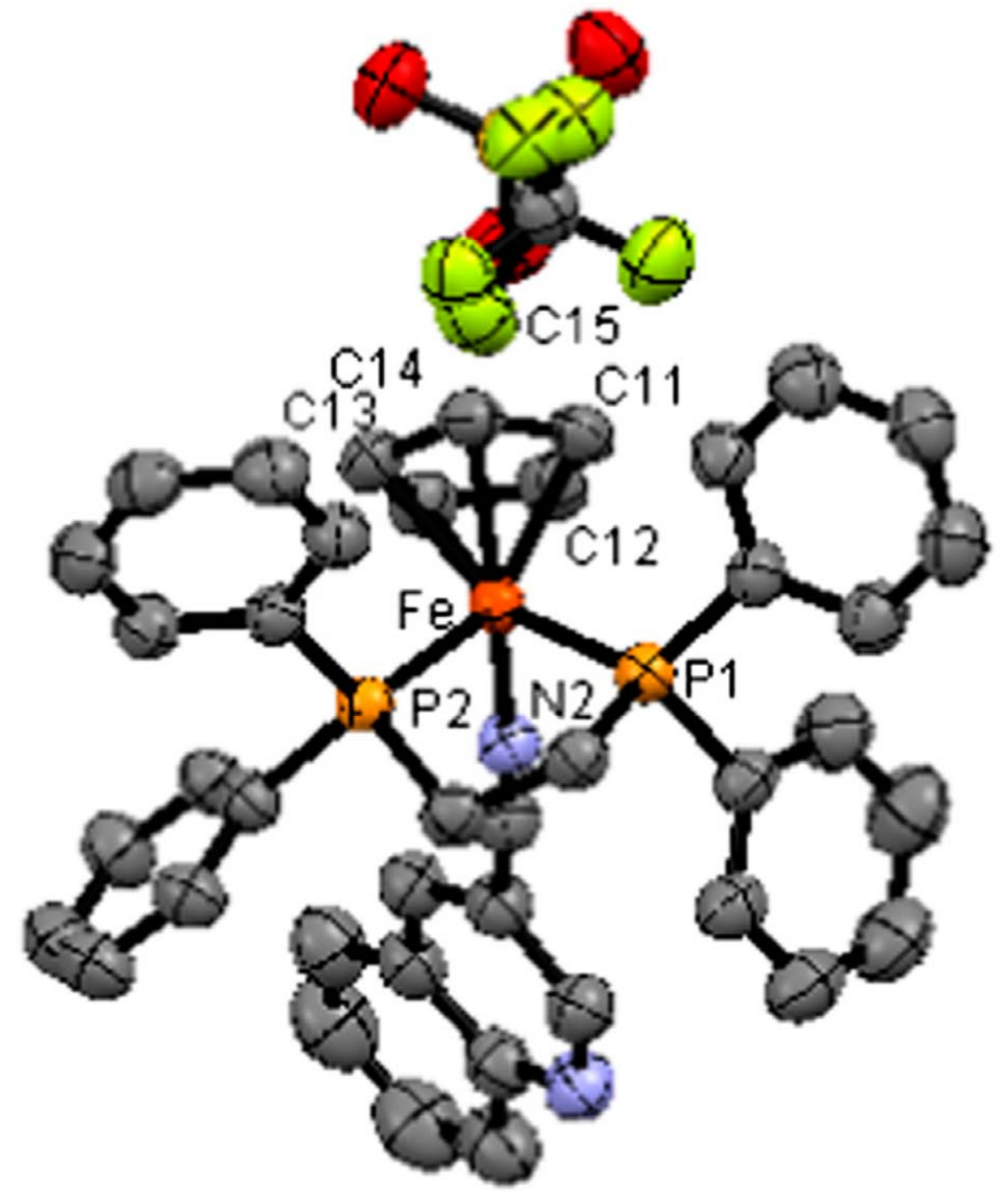

678

679 
681

682

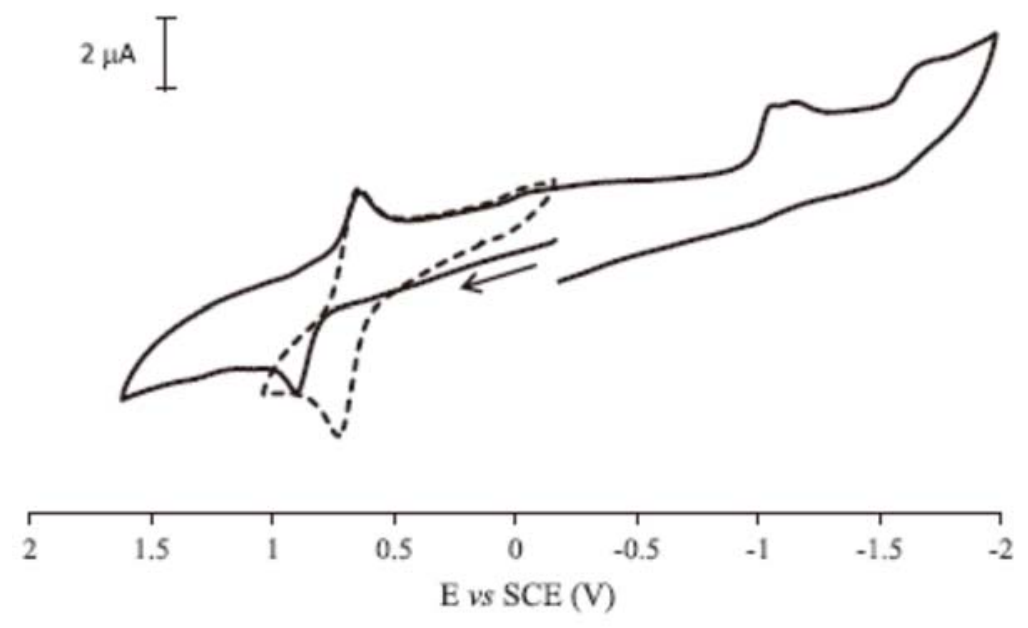

683

684 
686

687

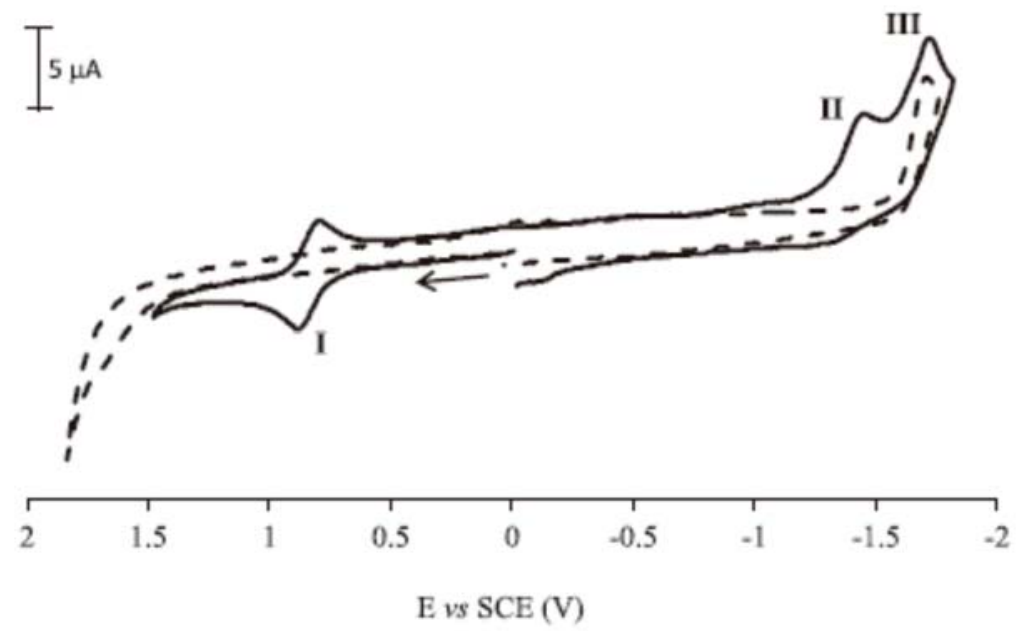

688

689

690 
692

693
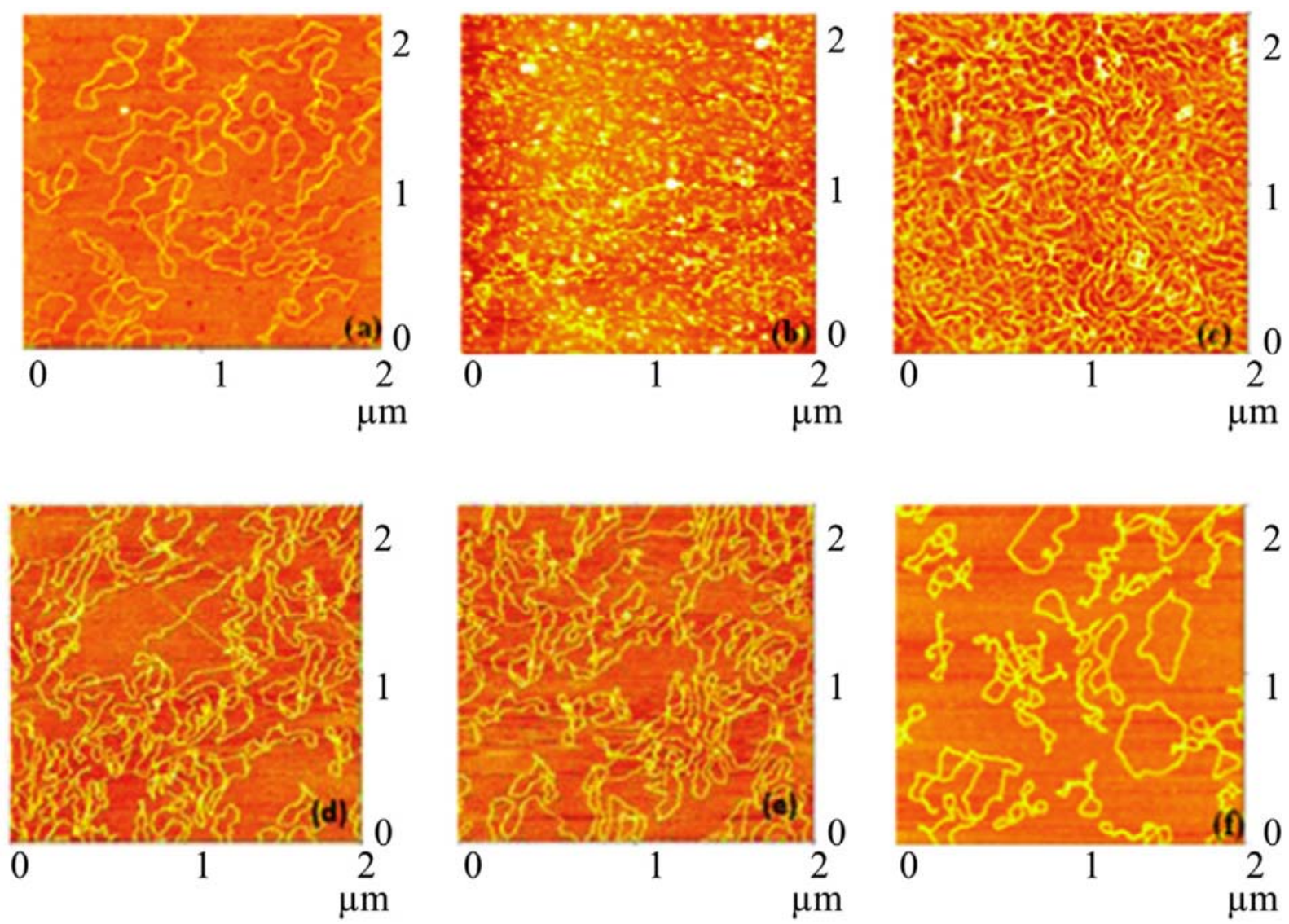

694 $\stackrel{2}{2}$ 2 